\title{
THE SOCIAL DIMENSION OF AUTONOMY
}

\author{
Antti Kauppinen
}

The ideology of atomistic individualism is a pervasive and familiar feature of late capitalist modernity. The following quote from a bestselling self-help book may serve as a graphic illustration:

You must recognize that you alone are the source of all the conditions and situations in your life. You must recognize that whatever your world looks like right now, you alone have caused it to look that way. The state of your health, your finances, your personal relationships - all of it is your doing, yours and no one else's. ${ }^{1}$

There is a kind of appeal to this sort of thinking. We take pride in being independent thinkers and doers, and we want to feel we are in control of our lives. We believe in personal responsibility, in blaming and praising people for actions that are up to them. Yet the injunction to shoulder all responsibility for everything is manifestly absurd. Surely our powers of controlling our lives are not magical. It is common sense that we acquire and exercise our capacities for self-determination and autonomy in interaction with others. The kind of animals we are do not spring out of the earth like mushrooms; it is ridiculous to suggest that there are no social conditions for autonomous lives. This is no doubt a truism. However, it gives rise to a real challenge: just what kind of social relationships are compatible with - or perhaps even necessary for - autonomous agency? If and when we value autonomy and wish to promote it, what should we do, beyond granting people rights against interference?

Traditional philosophical accounts of autonomy have focused on the capacities and characteristics of individuals that are required for them to count as self-determining and responsible, paying little heed to social conditions that might be harmful or conducive to acquiring

${ }^{1}$ M. Hernancki, The Ultimate Secret to Getting Absolutely Everything You Want, New York, Berkley, 2001, xii, 47. Quoted in B. Ehrenreich, Nickel and Dimed. On (Not) Getting By in America, New York, Henry Holt, 2005, pp. 81-82. 
or exercising these capacities. Recoiling from such views, those who emphasise how social power relations shape our very identities and how unconscious drives guide our behaviour have sometimes claimed that autonomy is just a harmful fiction: there is no real self, and even if there were one, it would not be in control. Nonetheless, even these radicals sign their works and speak of resistance, suggesting that their real beef is not with autonomy itself but more likely particular, individualistic conceptions of it. Perhaps it is not necessary, however, to conceive autonomy like that. Perhaps we can think of authentic selfdetermination as an intersubjective achievement, and thus avoid both unrealistic atomism and social determinism. This alternative has become a central starting point in recent debates in political philosophy around communitarianism, feminism and critical theory.

In this essay, I will examine systematically what a social or relational or intersubjectivist conception of autonomy might look like, what it would add to individualist theories, and what normative consequences it would have for liberal political philosophy. I begin with a brief look at the concept of autonomy and leading contemporary individualist theories (1). I then distinguish three respects in which autonomous agency depends on a sufficiently conducive social environment. First, as communitarians, feminists and psychoanalytically inspired philosophers have convincingly shown, acquiring the evaluative and motivational capacities needed for authentic self-determination is a result of a socialisation process that enables the child to grasp distinctions in value, challenge prevailing conventions, and order its first-order desires accordingly (2). As this literature is already well known and much discussed, I will be content with a brief overview. However, the second kind of intersubjective condition for autonomy, the psychological conditions for exercising these capacities and skills to shape an authentic self and lead an autonomous life, are less familiar. As Axel Honneth, above all, has argued, without a positive set of attitudes toward oneself - self-confidence, self-respect and self-esteem - one will not be able to make use of one's autonomy-constituting capacities. The development of these second-order capacities for autonomy, as they might be called, requires interpersonal recognition as a matter of empirical fact (3). I argue, however, that Honneth's view, as it stands, suffers from two basic weaknesses. First, it is premised on a problematic conception of the role of desire in autonomous agency, and needs to be supplemented by a normative competence account of individual autonomy capacities (4). Second, since the significance of recognition for autonomy is mediated through subjective experience, it cannot 
account for cases in which the exercise of autonomy-constituting capacities is hindered by objective relations of domination that are not experienced as such. Thus I argue for adding a third kind of intersubjective condition for autonomy, according to which having a social standing that makes available participation in valuable activities - a standing defined by the absence of domination, marginalisation and emotional exclusion - is directly constitutive of being autonomous, since it is, together with competitive material resources, the external condition of exercising effective autonomous control over one's life (5). In short, I argue that the exercise of autonomy-constituting individual capacities requires what Hegel calls 'being at home' in the social world, a condition that involves both the subjective experience of recognition and the objective fact of recognition. Such a strongly intersubjective view has potentially wide-ranging implications for a political theory like liberalism that takes individual autonomy as a central focus (6).

\section{The Concept and Conceptions of Autonomy}

Autonomy is a theoretical concept, though it has by now acquired some everyday resonance. Still, unlike the case of an ordinary language concept like knowledge, there is no point comparing theoretical proposals with ordinary use or linguistic intuitions. We can assess whether one or another way to understand it is better only in terms of a fixed theoretical purpose. In other words, we must fix the theoretical role of autonomy to pass judgement on different accounts of what it takes to fulfil that role. My topic in this essay is personal autonomy, which is, in the first instance, a characteristic of some persons or agents, rather than particular choices, actions or motives - even if the best way to approach what makes agents autonomous may be through investigating conditions for autonomous choice or action. Though it is intimately related to moral autonomy - roughly, the ability to govern oneself according to moral principles - and political autonomy - the ability to take part in collective-will formation - it is conceptually distinct.

I will approach the distinctive theoretical role of autonomy in terms of three widely accepted main contrasts that define what philosophers in general talk about when they talk about (personal) autonomy. ${ }^{2}$ First, autonomy contrasts with mechanism; an autonomous action does not

${ }^{2}$ In arguing that there is a unitary, commonly accepted core to the concept of (personal) autonomy (as opposed to conceptions of it), I am rejecting the view that there is 
follow from earlier states of affairs like clockwork or a pre-programmed reaction. If there is causal determination, it must be of a distinctive kind that allows for conscious, goal-seeking behaviour. Second, autonomy contrasts with lack of self-control due to volitional or motivational disorders. Autonomous agents are not constantly driven by random urges, desires or rash judgements, but are in some sense in charge of themselves. And finally, autonomy contrasts with heteronomy, by which I mean here that one's conception of what is worth doing does not result from undue influence by others (or physiological failure) but is rather a response to considerations bearing on the issue.

These contrasts highlight, respectively, the elements of purposive agency, self-determination and authenticity that are essential to any recognisable notion of autonomy. ${ }^{3}$ Agents whose actions are not governed by simple mechanism, alien motives or heteronomous influence but are instead authentically self-determining can meaningfully count as authors of their own actions and co-authors of their own lives when they are able to consistently exercise this capacity. This has several consequences to how it makes sense for others to relate to them. First, autonomous actions reveal who the agent is. They are, as Susan Wolf and Gary Watson put it, deeply attributable to the agent. ${ }^{4}$ They disclose the agent's character to others, expressing her practical identity. Since autonomous actions flow from the agent's own commitments, she can meaningfully be held answerable for them. Second, since autonomous agents are capable of forming views on what is worth doing in light of pertinent considerations and acting on them, it is fair to hold them to behavioural expectations that could in principle be justified to them. In other words, they are fit to be held fully responsible for their actions. It makes sense to praise or blame them for their actions, as well as to engage in practical dialogue with them to convince them. Third, when autonomous agents exercise the abilities that make them fit to be held

a plurality of distinct notions that are often confused. Nomy Arpaly, for example, distinguishes eight "senses" of "autonomy" (N. Arpaly, Unprincipled Virtue, Oxford, Oxford University Press, 2003, pp. 117-130), but fails to see that the central ones are aspects of a single notion rather than distinct, as she claims.

${ }^{3}$ At this level of abstraction one must naturally be careful not to formulate authenticity and self-determination in terms that presuppose an individualist conception of autonomy.

${ }^{4}$ G. Watson, 1996, S. Wolf, Freedom within Reason, Oxford, Oxford University Press, 1990. 
responsible, they are in an important sense free. ${ }^{5}$ As free and responsible, these agents are entitled not only to full moral consideration but also to a say in how they should be treated by others. Because autonomy is essential for full participation in public deliberation, it is a central democratic value. Because it is essential to leading one's life according to one's own convictions, it is a central liberal value.

What, then, constitutes being autonomous? According to individualist conceptions, being autonomous is solely a matter of having certain kinds of psychological capacities. Contemporary individualists can be divided into two basic groups, proceduralists and substantivists. Procedural views are content-neutral: according to them, any preference can count as autonomous, provided it is formed in the right way or fits in the right way in the agent's motivational structure. Thus, according to hierarchical theories of Harry Frankfurt and Gerald Dworkin, our standpoint on the world is constituted by the desires that we reflectively endorse. For them, reflective endorsement is a matter of, roughly, desiring to desire as one does. ${ }^{6}$ A world-directed or first-order desire is autonomous if the agent has a suitable second-order desire (a desire about desires) to the effect that the first-order desire be motivationally effective. In such a case, the agent is said to identify with the first-order desire, which thus constitutes her will. Desires that we do not desire to have, in contrast, are in the relevant sense external to ourselves; we are alienated from them, and if they lead us to act in spite of ourselves, we are mere bystanders to our own actions.

Critics of the hierarchical model within the proceduralist tradition have focused on two questions: are higher-order desires really suitable for drawing the limits of the agent's real self, and is the origin of higherorder desires really irrelevant to autonomy? To begin with, why is it that higher-order desires should count as somehow representing the agent's own view or her real self - what gives them such authority? There is no guarantee, notably, that higher-order desires represent our values: we might intelligibly disapprove of them, and thus, arguably, alienate ourselves from them. To solve this problem, evaluativists like

${ }^{5}$ For the connection between fitness to be held responsible and freedom, see P. Strawson, "Freedom and Resentment" in G. Watson, Free Will, 2nd ed., Oxford, Oxford University Press, 1962, pp. 72-93 and in P. Pettit, A Theory of Freedom, Cambridge, Polity Press, ch. 1, 2001.

${ }^{6}$ See the essays collected in H. Frankfurt, The Importance of What We Care About, 1988 and G. Dworkin, Theory and Practice of Autonomy, Cambridge, Cambridge University Press, 1988. 
Gary Watson, roughly propose that we see the agent's own standpoint or true self as constituted by her valuational system or evaluative beliefs. ${ }^{7}$ Autonomy as self-determination, then, is achieved when the agent's motivational system or desires is aligned with her valuational system. However, this still leaves the problem of origin open: if we admit that it is possible to get agents to form desires that do not represent their true self, why would it not be possible to get agents to form inauthentic higher-order desires or evaluations? As John Christman puts it, "a person can be manipulated and conditioned to such an extent that she gains a coherent and integrated set of desires as a result, but one which is totally the result of external manipulation". Thus, Christman proposes that autonomous desires are those resulting from a process that the agent would not have resisted, had she reflected on them in a minimally rational and self-aware fashion. ${ }^{9}$ In a similar spirit, but building on an evaluativist rather than hierarchical model, Al Mele suggests that what makes 'value engineering' autonomy undermining is that it bypasses the agent's capacities for rational control of their mental lives, such as those of assessing their values and principles and modifying their motives accordingly. ${ }^{10}$

The essence of all the above procedural individualist views is that the content of an autonomous agent's evaluative beliefs and desires does not matter. Some find this problematic since it allows one to autonomously choose a life of subservience and non-autonomy, for example. Consequently, they argue that there are certain specific things that an autonomous person must care about, centrally continuing to be

7 G. Watson, "Free Agency" (1975) in G. Watson, Agency and Answerability. Selected Essays, Oxford, Clarendon Press, 2004, pp. 25-26; he calls the view "Platonistic". Frankfurt's talk of "reflective endorsement" is also sometimes construed as a version of evaluativism (for example, M. Smith, The Moral Problem, Oxford, Blackwell, 1994, p. 134), but he vehemently denies this, emphasising volitional necessity (inability and unwillingness to will otherwise) as the criterion of desire ownership in recent work (see H. Frankfurt, The Reasons of Love, Princetown University Press, 2004).

${ }^{8}$ J. Christman, "Autonomy and Personal History," Canadian Journal of Philosophy, vol. 21, no. 1, 1991, pp. 9n19.

9 ibid., p. 21. Robert Young's account ("Autonomy and Socialization," Mind, vol. 89, 1980, pp. 565-576) differs in that for him, reflective acceptance now of the processes that led to preference-formation or identification is sufficient for autonomy, while Christman requires reflective acceptance then, to avoid the problem that acceptance now can be objectionably conditioned.

${ }^{10}$ A. Mele, Autonomous Agents, Oxford, Oxford University Press, 1995, pp. 168-172, 183-184. 
autonomous in the future. ${ }^{11}$ Another critique of pure proceduralism takes its departure from the link between autonomy and accountability, or fitness to be held fully responsible. The key idea is that it is possible to meet any procedural conditions, but still be intuitively less than fully accountable for one's choices. This is the case when one's values or desires lack sufficient grounding in what is truly valuable or desirable. Such agents may be self-governing in a narrow sense, even minimally rational in the sense of internal consistency, but still incapable of responsibly directing their lives, because they fail to understand the true significance of their choices. According to normative competence accounts of the sort defended by Susan Wolf, and John Fischer and Mark Ravizza, unless the content of one's evaluative beliefs and desires is at least moderately 'reasons-responsive', one does not have the kind of abilities that would enable one to guide one's life in a responsible manner, and correspondingly are not autonomous. ${ }^{12}$ I will defend this kind of view of autonomy-constituting capacities in section 4 .

\section{The Social Conditions of Becoming Autonomous}

The roots of intersubjectivism can be found already in Aristotle's doctrine that man is a political animal - an animal, that is, whose speciesspecific potential is actualised only in and through active participation in the life of the polis - and, as we will see, this type of argument is still used by some contemporary communitarians. It was Fichte, however, who first explicitly formulated an intersubjective condition specifically for autonomy, or "the exercise of free efficacy", 13 in his Foundations of Natural Right. His argument is a transcendental, a priori deduction

\footnotetext{
${ }^{11}$ See, for example, T. Hill, "Servility and Self-Respect" in Autonomy and SelfRespect, Cambridge, Cambridge University Press, 1991, pp. ?. See also M. Oshana, "Personal Autonomy and Society," The Journal of Social Philosophy, vol. 29, no. 1, 1998, pp. 81-102.

${ }_{12}$ Wolf 1990, R. J. Wallace (Responsibility and the Moral Sentiments, Cambridge, Mass., Harvard University Press, 1994), Fischer and Ravizza 1998. Wolf herself (and Wallace after her) use 'autonomy' for the sort of Kantian views requiring contracausal freedom that she rejects, but it makes more sense to see her 'Reason View' as an alternative conception of autonomy rather than as an alternative to autonomy. Similarly, Pettit and Smith (1996) ("Freedom in Belief and Desire," reprinted in Watson, 2003, pp. 388-407) use the term "orthonomy" for their normative competence account, which I class here as another variant of this conception of autonomy.

${ }^{13}$ J. G. Fichte, Foundations of Natural Right, ed. F. Neuhouser, trans. M. Baur, Cambridge, Cambridge University Press, 1796/2000, \$1.
} 
from the conditions of possibility of self-consciousness, which in turn is necessary for free choice. It goes roughly as follows. To will anything, I must posit (be conscious of) an independent, external world, since acting otherwise would be superfluous (everything would change if I merely thought so). To posit something as an object is to experience it as something that constrains my spontaneity. ${ }^{14}$ As a practical subject, I must thus experience myself as a finite individual. To set ends and make plans, to deliberate consciously, I must also be aware of my unconstrained ability to set an aim for myself and act on it, my free efficacy. This kind of practical self-consciousness requires that "the subject's efficacy is itself the object that is perceived and comprehended". ${ }^{15}$ But how can I experience my spontaneous activity as such, as unconstrained, if at the very moment I make it an object I (by definition) experience it as something that constrains my spontaneity? That is, how can I catch myself in the act, so that the I that is experienced and the I that experiences fall together? An infinite regress or circle threatens when the I chases its tail in vain. Fichte argues that it is possible to break the circle only if I am conscious of "being-determined to be self-determining"16 - when the object that constrains my spontaneity indirectly reveals the spontaneity, allowing me to catch it from the corner of my eye, so to speak. Crucially, he notes that this is the case when I experience myself as being called on or summoned to act by another free and rational subject. When I experience something as a summons (Aufforderung), I do not experience it as a causal force that determines me to act in a certain way, but as a demand addressed to me that calls on me to decide whether or not to go along, that is, to determine myself, to exercise my spontaneity. Only in and through this reaction of the other to me do I become aware of my spontaneous ability to act as such, he claims.

Now, Fichte continues, the summoner must take me to be a free rational being to try to influence me in this way: "The purposiveness of the summons is conditional on the understanding and freedom of the

14 "[T] he nature of an object is such that, when it is comprehended by a subject, the subject's free activity is posited as constrained." Fichte, 1796/2000, \$3, p. 31. For the idealist, the object is still transcendentally (and from the perspective of the philosopher in the theoretical mode) a result of the subject's free activity, as is everything that exists.

15 ibid., $\$ 3$, p. 31.

16 ibid. 
being to whom it is addressed". ${ }^{17}$ To be able to do this, the summoner $\mathrm{him} /$ herself must have the concepts of freedom and reason, and thus be a rational being. Seeing that it issues from a free and rational being is thus part of what I have to recognise to take the summons as such and reach self-consciousness - so that recognising a free and rational being outside myself is necessary for me to reach self-consciousness. Since the summoner must do likewise as a precondition of his very act, the recognition as free and rational is necessarily mutual: "One cannot recognize the other if both do not mutually recognize each other; and one cannot treat the other as a free being, if both do not mutually treat each other as free". ${ }^{18}$ In this way, mutual recognition and limitation of freedom (which, according to Fichte, is the essence of the concept of right) turn out to be necessary conditions of self-consciousness (consciousness of one's free efficacy) and consequently autonomy.

Fichte's theory is groundbreaking in many ways. It problematises something that seems self-evident - my awareness of my own freedom to act - and argues that it depends on a linguistically mediated intersubjective relationship, thus decisively (even if not necessarily consistently ${ }^{19}$ ) breaking the frame of the early modern philosophy of the subject. In so doing, it opens a path along which Hegel, Mead and Habermas have each achieved their most important insights. Nonetheless, even taken at face value, it is very limited as an intersubjective theory of autonomous agency. While awareness of one's ability to set ends may be a necessary condition of autonomy, it is far from sufficient, as the discussion of individualist conceptions showed.

7 ibid., $\$ 3$, p. 35 .

18 ibid., $\$ 4$, p. 42 . Fichte draws the conclusion that since we all need other human beings to become human, "if there are human beings, there must be more than one" $(\$ 3$, p. 37$)$. How does it all get started, then? Well, another, non-human rational being must have brought up the first human beings ( $\$ 3$, p. 38$)$ - that is, Fichte turns a 'priming problem' for his theory into a proof of the existence of God!

19 A. Honneth, "Die transzendentale Notwendigkeit von Intersubjektivität" in Unsichtbarkeit. Stationen einer Theorie der Intersubjektivität. Suhrkamp, Frankfurt, 2003, pp. 28-48.; J. Habermas ("Individuation Through Socialization: On George Herbert Mead's Theory of Subjectivity” in Postmetaphysical Thinking, Cambridge, Mass., MIT Press, 1992a, pp. 149-204), and R. Neuhouser ("Introduction" in Fichte, 2000), for example, raise serious concerns about the consistency and sufficiency of Fichte's account. How do I recognise that $I$ am being summoned, if I am not already in some inchoate way aware of myself? (At most, intersubjectivity is a condition of the move from a pre-reflexive to reflexive awareness of oneself - which is not nothing, of course.) How can my transcendental ego be in any sense the source of everything that exists, as idealists like Fichte claim, if there must be others? 
Some contemporary communitarians aim to provide a more farreaching account of the social conditions for becoming autonomous. The basic elements of a generic conception of embedded autonomy can be found in the work of Charles Taylor and Michael Sandel. First, we can revise our ends only when holding other ends fixed; Taylor argues that 'radical choice' is no choice at all, just plumping for one or another alternative without grounds. ${ }^{20}$ Second, not just any given ends provide support for autonomous choice, since it is not a matter of simple weighing of the strength of one's desires. ${ }^{21}$ Instead, thirdly, autonomous choice is choice in light of one's constitutive ends (Sandel) or strong evaluations (Taylor), commitments and valuations that define who we are and want to be and make possible qualitative distinctions among motives - for example, resisting a temptation to have one's nose operated on because it would be vain, even if one believes this course of action would best satisfy one's existing desires. Thus it calls for selfknowledge and self-understanding - we must know which of our ends are revisable and which are such that stepping back from them would amount to becoming a different person..$^{22}$

Finally, this brings in community in two ways. Since our identity, in part, precedes autonomous choice rather than results from it, we can only become autonomous when we have a sense of where we stand, an orientation toward the good. At least initially, this orientation is provided by communally defined roles (being a Catholic, being a father, and so on) that involve definite ideals of what is noble and what is base, what is worth wanting and what is not. ${ }^{23}$ These identities may be essentially shared, so that it does not make sense to be a nun, for example, except in the context of an ongoing social practice. However, as Taylor, in particular, emphasises, community does not enter the picture merely through providing content for identities, but also through being a precondition for having a language in which to articulate the qualitative distinctions involved in strong evaluation. Language, Taylor argues, following what he calls the 'expressivist' Romantic tradition of Herder and Humboldt, is constitutive of human attitudes, not merely a

${ }^{20}$ C. Taylor, Hegel, 1977, pp. 29-30.

${ }^{21}$ Sandel, 1998, pp. 159-160; C. Taylor, Human Agency and Language. Philosophical Papers I., Cambridge, Cambridge University Press, 1985a, pp. 25-26.

${ }_{22}$ Sandel, 1998, pp. 58-59; Taylor, Human Agency and Language, p. 34; C. Taylor, Sources of the Self. The Making of Modern Identity, Cambridge, Mass., Harvard University Press, 1989, p. 27.

${ }^{23}$ See, for example, A. MacIntyre, After Virtue, 2nd ed., Notre Dame, University of Notre Dame Press, 1984, pp. 220-221. 
means for representing them. As self-interpreting animals, who we are depends in part on who we take ourselves to be, on how we understand ourselves. We start out with an inchoate sense of the import of a situation - something bothers me about the tone of a remark a friend made - and try to find the right words for it; perhaps reflection leads me to believe using that tone in that context bespoke of envy. Coming to formulate the matter in this way changes how one feels about the situation, given that there is an internal relation between our emotions and our interpretation of their objects. This enhanced sense of significance, made possible by linguistic articulation, enables us to form new kinds of goals and relationships to others. ${ }^{24}$ Thus it is essential for the sort of attitudes that constitute strong evaluations. And since there is no private language, this is a strong argument for what Taylor elsewhere calls the 'social thesis', the claim that human beings "only develop their characteristically human capacities in society", that "living in society is a necessary condition ... of becoming a fully responsible, autonomous being". ${ }^{25} \mathrm{He}$ argues further that eventually conceiving of alternative ways of life in a way that is an essential component of the kind of autonomy that liberals and libertarians value requires including the very idea of going against prevailing conventions - is possible only within particular social and historical contexts. ${ }^{26}$

In sum, communitarians argue that belonging to a suitable kind of community is what makes possible having identities that provide constitutive ends, having the kind of evaluatively rich language that enables articulating and revising these ends, and developing an imagination that allows one to envision living differently from one's role models, all capacities necessary for autonomous agency. Many feminists ${ }^{27}$ and psychoanalytically influenced theorists ${ }^{28}$ have presented similar views

${ }^{24}$ For example, Taylor, Human Agency and Language, pp. 102, 234.

${ }^{25}$ C. Taylor, Philosophy and the Human Sciences. Philosophical Papers II, Cambridge, Cambridge University Press, 1985, pp. 190-191.

${ }^{26}$ Taylor, Philosophy and the Human Sciences, pp. 204-206. See also J. Raz, The Morality of Freedom, Oxford, Clarendon Press, 1986, p. 162 and Y. Tamir, Liberal Nationalism, Princeton, Princeton University Press, 1993, p. 30.

${ }^{27}$ See, for example, D. T. Meyers, Self, Society, and Personal Choice, New York, Columbia University Press, 1989; M. Friedman, Autonomy, Gender, Politics, Oxford, Oxford University Press, 2003, and C. Mackenzie \& N Stoljar (eds.), Relational Autonomy: Feminist Perspectives on Autonomy, Agency, and the Social Self, Oxford, Oxford University Press, 2000.

${ }^{28}$ See S. Scheffler, Human Morality, Oxford, Oxford University Press, 1992, and J. D. Velleman, “A Rational Superego?” The Philosophical Review, vol. 108, 1999, pp. 529-558. 
and further evidence supporting the contention that, as a matter of empirical fact, only participation in particular kinds of social relationships enables one to learn the sort of evaluative and motivational capacities required for being autonomous. This view is now broadly accepted, though its implications can be a matter of fierce debate.

\section{Recognition and the Psychological Conditions of Exercising Autonomy}

As the accounts discussed in the previous section show, acquiring autonomy-constituting capacities plausibly depends on intersubjective relationships. However, to be autonomous, one needs more than the simple ability to act autonomously; one must be in a position to exercise this ability. This is not optional, since it is only through the exercise of autonomy skills that one shapes an authentic self in the first place. Thus people must actually exercise a fair degree of control over the direction of their lives to count as autonomous. As Joseph Raz stresses, it is the exercise and not the mere capacity for autonomy that we hold so dear. ${ }^{29}$ It is essential to my argument that this exercise of selfdetermination can be supported or defeated both by internal and external conditions. In this section, I examine accounts that focus on the former, and return to the latter in section 5 .

The second family of empirical intersubjectivist conceptions of autonomy thus focuses on the influence of intersubjective relationships on agents' second-order capacities for autonomy - in other words, psychological capacities that are required for the agent to exercise their first-order, autonomy-constituting capacities, "to actually make use of their autonomy" ${ }^{30}$ Broadly speaking, the thesis is that the evaluative and motivational capacities of an agent (whether or not they are acquired only in particular social relationships) are as good as useless unless she also trusts in herself - that is, unless she has the capacity for particular self-directed emotional or affective attitudes. ${ }^{31}$ Autonomy

29 "It's hard to conceive of an argument that possession of a capacity is valuable even though its exercise is devoid of value ... The ideal of autonomy is that of autonomous life. The capacity for autonomy is a secondary sense of 'autonomy'" (Raz, 1986, p. 372).

${ }^{30}$ Nancy Fraser and Axel Honneth, Redistribution or Recognition? A Political Philosophical Exchange. Verso, London, 2003, p. 181.

${ }^{31}$ I do not mean to suggest that positive attitudes toward oneself exhaust the psychological conditions for the exercise of autonomy. There are also the so-called 
cannot be understood merely in terms of the structure of beliefs and desires. As Axel Honneth puts it in a paper co-authored with Joel Anderson, to be autonomous, we must be able "to trust our own feelings and intuitions, to stand up for what we believe in, and to consider our projects and accomplishments worthwhile". ${ }^{32}$ The next step is the claim that the ability to adopt such attitudes depends on suitable interpersonal relationships. A proponent of this type of intersubjective account thus has a double burden of proof: he or she must show both that autonomy requires a certain kind of attitude toward oneself and that autonomy-conducive relationships are at least empirically necessary for having such attitudes.

Theories of this type have been proposed by Paul Benson in a series of articles and Honneth in his The Struggle for Recognition and subsequent works. ${ }^{33}$ I will focus here on Honneth, since his view is more comprehensive, both theoretically sophisticated and empirically supported. In these respects it represents a step forward from vague and sketchy suggestions in this direction by some feminist and communitarian theorists. Honneth's methodological starting point is a solid Hegelian insight: the dependence of autonomy on social relationships is revealed when the disruption of those relationships leads to reduction in one's ability to make autonomous choices. The normally invisible intersubjective dependence manifests itself when there is a problem. Examining such disruptions and their effects systematically we can construct a theory of autonomy-conducive relationships that is firmly rooted in everyday experience and psychological research.

Aiming to naturalise early Hegel's account, Honneth argues that it is an empirical matter of fact we can acquire and sustain such attitudes toward ourselves only when others adopt corresponding attitudes toward us - in other words, if we are recognised by those whose attitudes we in turn regard as authoritative, that is, those whom we recognise. Because these attitudes are necessary for autonomy, autonomy

'executive virtues' like temperance, courage and fortitude that may be needed for one to make judgements and stand by them (see P. Pettit \& M. Smith, "Practical Unreason," Mind, vol. 102, 1993, pp. 76-77).

${ }^{32}$ Joel Anderson and Axel Honneth, "Autonomy, Vulnerability, Recognition, and Justice", in eds. Anderson and Christman, 2005, 127-149. p. 130. I will henceforth attribute the views presented in this important paper to Honneth without qualification, since they cohere with what he says elsewhere.

${ }^{33}$ For P. Benson, see "Freedom and Value", Journal of Philosophy 84, 1987, pp. 465486; "Free Agency and Self-Worth", Journal of Philosophy 91, 1994, pp. 650-668. 
depends on mutual recognition. As we have seen, insofar as such theses are found in Fichte and Hegel, they are most plausibly read as transcendental arguments about the conditions of possibility of particular kinds of self-relation. Honneth, however, believes that in contemporary 'postmetaphysical' context, what is needed is "a reconstruction of [Hegel's] initial thesis in the light of empirical social psychology" ${ }^{34}$ I will next summarise the arguments and evidence he presents for the necessity of three kinds of self-relation, self-confidence, self-respect and self-esteem, for exercising autonomy-constituting capacities, and the empirical dependence of these self-relations on being correspondingly recognised by others. It must be noted at the outset that Honneth does not always formulate the importance of recognition in terms of its contribution to autonomy, but also talks about recognition as a condition of self-realisation (Selbstverwirklichung), personal integrity, intact self-relation and personal identity-formation. It is not exactly clear what the relationship of these concepts is to autonomy; on the face of it, they are far from equivalent, though no doubt related. In the following, I will focus solely on recognition as a condition of autonomy.

\subsection{Self-Confidence}

The first recognition-mediated self-relation in Honneth's schema is basic self-confidence, understood as a positive affective attitude toward one's own desires. He draws empirical support for the recognitiondependence of self-confidence from object-relations theory. According to its leading proponent, Donald Winnicott, the child and the mother initially form an undifferentiated intersubjectivity. When the mother gradually returns to life after the initial 'holding phase', there is a crisis for the infant that manifests itself in tantrums and aggression toward the mother. For Winnicott, this leads both child and mother to see each other as separate subjects with independent needs. At the same time, they become aware of their mutual dependence. As the mother continues to provide reliably for the needs of the child in spite of its manifesting aggressive impulses, the child can begin to express what it wants without fear of being abandoned. As Honneth puts it, "In becoming sure of the 'mother's' love, young children come to trust themselves,

${ }^{34}$ Axel Honneth, The Struggle for Recognition. The Moral Grammar of Social Conflicts, Polity Press, Cambridge, 1995, p. 68. 
which makes it possible for them to be alone without anxiety". ${ }^{35}$ The idea seems to be that when the child is not rejected because of unruly impulses, it comes to see the satisfaction of its basic needs and desires as having inherent value for the other in spite of diverging from the other's needs and desires. In internalising the other's positive valuation, one comes to see one's basic needs for physical and psychological integrity as worth being satisfied and gains "strength to open up to himself or herself in a relaxed relation-to-self". ${ }^{36}$ This, according to Honneth, is essential for autonomy, since "self-trust has to do with the affectively mediated perceptual capacities by which what is subjectively felt becomes material for deliberation in the first place". ${ }^{37}$ These "body-bound drive impulses, the 'id' in Freud's sense "push the growing child into the direction of "a higher degree of individuation in its articulation of needs". 38

If recognition in the form of love and caring is empirically necessary for openness to desires that push one away from social conformity, in particular those related to the body, their absence or active misrecognition should manifest itself in disruption of this self-relationship. Again drawing on empirical studies, Honneth argues that this is indeed the case. Misrecognition here consists of physical and psychological abuse, in the worst case torture and rape, resulting in, on the one hand, "lasting damage to one's basic confidence (learned through love) that one can autonomously coordinate one's own body" ${ }^{39}$ and on the other, the inability of victims to "trust their desires to be authentically their own" ${ }^{40}$ Without confidence in the authenticity or worth of what one wants or the related sense of being at home in one's body, the exercise of the capacity of assessing one's desires and acting on the assessment is impaired. Thus one's autonomy - apparently understood here roughly

\footnotetext{
${ }^{35}$ Honneth, The Struggle for Recognition, p. 104. Following Winnicott, Honneth speculates that this original dialectic of boundary-dissolution and boundaryestablishment is behind adult affective relationships as well.

${ }^{36}$ Honneth, The Struggle for Recognition, p. 105.

37 Anderson and Honneth, "Autonomy, Vulnerability, Recognition, and Justice", p. 133.

${ }_{38}$ Axel Honneth, 'Objektbeziehungen und postmoderne Identität', in Unsichtbarkeit. Stationen einer Theorie der Intersubjektivität. Suhrkamp, Frankfurt, 2003, p. 149 (my translation).

${ }^{39}$ Honneth, The Struggle for Recognition, p. 132. It is not immediately clear how Honneth moves from trust in one's needs and desires to trust in autonomous coordination of one's body.

${ }_{40}$ Anderson and Honneth, "Autonomy, Vulnerability, Recognition, and Justice", p. 134.
} 
on the hierarchical model - is diminished because of emotional misrecognition, and shown to depend on positive recognition.

\subsection{Self-Respect}

To make independent choices, we have to be willing to listen to ourselves, and acquiring the basic self-confidence required for this depends, as a matter of fact, on being loved. However, making choices and especially acting on them require also that we have faith in our practical judgement, that we are not cowed by the opinions of others. It is one thing to defer to someone else's judgement on occasion and another to defer to it by default. To be autonomous, therefore, one must consider oneself to have an equal standing and authority in making judgements on the basis of generally acceptable reasons; in short, one must have self-respect. As Anderson and Honneth formulate it, "[i] f one cannot think of oneself as a competent deliberator and legitimate co-author of decisions, it is hard to see how one can take oneself seriously in one's own practical reasoning about what to do" ${ }^{41}$ The second thesis of Honneth's recognitional view of autonomy is, consequently, that self-respect, as a matter of fact, depends on a certain kind of recognition by others. Love alone will not suffice for this (though it no doubt involves respecting the loved one's take on the situation), since it is in the first instance a matter of responding to our needs and desires. What, then, does it take for us to be able to view ourselves as capable choosers, as agents deserving the respect of others in virtue of having a capacity to weigh reasons and act on them? The first step is naturally that we are consulted in disputes about what to do and that others in turn present us with reasons rather than, say, brute orders. However, this alone is not sufficient; to respect ourselves we must feel that others owe it to us to take our views into account, and this requires guarantees that we will be heard. So, according to Honneth, we can take ourselves to deserve respect only when there exist social or legal sanctions against treating us in ways that bypass our own judgement that is, when we are conscious of having rights (and duties). ${ }^{42}$ Once we

${ }^{41}$ Anderson and Honneth, "Autonomy, Vulnerability, Recognition, and Justice", p. 132.

${ }_{42}$ For example, Honneth, The Struggle for Recognition, p. 109. Honneth only talks about legally guaranteed rights, but he would hardly want to deny that self-respect was possible for respected members of, say, tribal communities without rule of law. 'Rights' must then be understood in a broader sense. 
can expect that our legitimate claims against others will be socially or legally enforced, we gain confidence in our judgement. Honneth quotes Joel Feinberg, according to whom "[h] aving rights enables us to 'stand up like men', to look others in the eye, and to feel in some fundamental way equal of anyone". ${ }^{43}$ As a form of recognition, granting rights differs in many ways from love: it does not require an emotional attachment and admits of historical development both in terms of including new groups of subjects and introducing new kinds of rights. ${ }^{44}$

Again, the dependence of self-respect on recognition in the form of rights and equal treatment is clearest in the breach. Being consistently excluded, ignored, or marginalised can lead to habitual passivity and timidity. Those who have some self-respect may feel shame or bitterness and be motivated to struggle for more comprehensive recognition. Others may sink into quiet obedience. To take a concrete example, Paul Benson discusses the persistent sense of shame associated with slavery. He points out that " $\mathrm{t}]$ he social mechanisms that sustained slavery did so in part by working to destroy slaves' sense of their competence to make their own decisions and manage their own lives". ${ }^{45}$ Less drastic but perhaps more widespread is the diminished selfrespect of many women in patriarchal societies. ${ }^{46}$ In each case, one is unable to exercise one's autonomy-constituting capacities, even if they should otherwise be intact, which shows that self-respect and the kind of recognition that makes it possible are empirically needed for being autonomous.

\subsection{Self-Esteem}

It might at first appear that self-confidence and self-respect would suffice for one to be able to exercise one's autonomy-constituting capacities. However, independent action requires more than faith in our general capacity for making judgements. We must also be convinced of

${ }^{4}$ J. Feinberg, Rights, Justice, and the Bounds of Liberty: Essays in Social Philosophy, Princeton, Princeton University Press, 1980, p. 143; quoted in Honneth, The Struggle for Recognition, p. 120.

44 Honneth, The Struggle for Recognition, pp. 110-118.

45 P. Benson, "Free Agency and Self-Worth", Journal of Philosophy, vol. 91, 1994, p. 659. Benson refers here to Orlando Patterson's study Slavery and Social Death, Cambridge, Mass., Harvard University Press, 1982.

46 For empirical data, see M. Friedman, "Autonomy and Male Domination" in J. Anderson \& J. Christman (eds.), Autonomy and the Challenges to Liberalism, Cambridge, Cambridge University Press, 2005. 
the worth of the particular projects and commitments we undertake and the particular character traits and abilities they require or express. In Rawls' words, "When we feel that our plans are of little value, we cannot pursue them with pleasure or take delight in their execution. Nor plagued by failure and self-doubt can we continue in our endeavours". ${ }^{47}$ Our projects and plans give content to our practical identities, making us the kind of people we are. If we are not able to value ourselves under certain descriptions or if we do not have faith in our own ability to carry out the plan - if we lack self-esteem - we are likely to give up on particular endeavours, even if we would otherwise confidently judge them best. In this way autonomy depends on self-esteem.

On the recognitional view, self-esteem requires that the identities and abilities of the agent are considered valuable within "a symbolically articulated - yet always open and porous - framework of orientation in which those ethical values and goals are formulated that, taken together, comprise the cultural self-understanding of a society".48 Anderson and Honneth call this dependence our semantic vulnerability: the significance attached to a way of being and doing is a linguistic matter, and as such is not controlled by an individual's intentions. Instead, it is a matter of connections established through use and repetition in language games, patterns of talk, action and attitude. What it means to be 'a union man', for example, depends on an evolving social process, a web of mutually reinforcing individual uses, and correspondingly varies between cultures and times. Where a negative stigma is attached to a practical identity, it is hard to value oneself under that description, and related projects and actions get closed off the deliberative screen, reducing autonomy. A sense of shame, characteristically felt when under a real or imaginary gaze of disapproving or taunting others, motivates one to hide and conform rather than go on with one's plans.

For Honneth, social esteem is tied to the contribution one makes to goals that are considered valuable in a society - it is, so to speak, a currency in which society rewards those who do a service to it. With modernity, social esteem becomes a matter of individual achievement

${ }^{47}$ Rawls, 1971, p. 440. Rawls treats 'self-respect' and 'self-esteem' as interchangeable, but it is plausible to regard him as talking about two different self-relations in Honneth's scheme.

${ }^{48}$ Honneth, The Struggle for Recognition, p. 122. 
rather than a predefined role or status hierarchy. Goals are shared only at a high level of abstraction and call for supplemental cultural interpretation - even if everyone agrees that, say, intelligence is valuable, it is still an open question what constitutes intelligence. ${ }^{49}$ As Honneth makes clear in his debate with Nancy Fraser, for him the symbolic value of individual achievements is central for issues of distribution as well: according to him, even collective action for wage rises is an attempt by workers to "throw the established evaluative models into question by fighting for greater esteem of their social contributions, and thereby for economic redistribution". ${ }^{50}$

To sum up, Honneth's view is that we can as a matter of fact only acquire self-confidence through being loved, self-respect through being treated as inviolable, and self-esteem through having our pursuits socially valued. In the absence of such attitudes toward ourselves, we are psychologically hindered from exercising our autonomyconstituting capacities of accessing our authentic desires and feelings, making judgements based on reasons deriving from them, and following through on the judgements. Thus, being recognised is an empirically necessary condition for being autonomous. ${ }^{51}$

\subsection{Empirical Intersubjectivism and Individualism}

I have now outlined how both acquiring autonomy-constituting capacities and having the psychological second-order capacities necessary

49 See Honneth, The Struggle for Recognition, pp. 123-127.

${ }^{50}$ Fraser and Honneth, Redistribution or Recognition?, p. 154 (emphasis mine). I have no room to address this debate properly, but Honneth does not seem to recognise how little market value has to do with being valued and how much it has to do with supply and demand - the fact that paper workers are better paid than metal workers has nothing to do with social esteem and everything to do with bargaining situations. Fraser and Habermas grasp this much better, and Honneth would be better served with the more cautious formulations about the relation between recognition and redistribution he uses in The Struggle for Recognition. He is also wrong in claiming that "the individualist achievement principle is also the one normative resource bourgeois-capitalist society provides for morally justifying the extremely unequal distribution of life chances and goods" (Redistribution or Recognition?, p. 148). Market libertarians like Nozick eschew reference to achievement or desert and talk instead about entitlement, which is an historical result of just acquisitions and transfers, which in turn can and will lead to unequal distributions (see R. Nozick, Anarchy, State, and Utopia, New York, Basic Books, 1974, ch. 7). Criticism of justifications of inequality, then, must likewise focus elsewhere than interpretations of the achievement principle.

${ }^{51}$ I have here abstracted away from the historical and cultural variations between different "recognition orders" (Fraser and Honneth, Redistribution or Recognition?, p. 137), configurations of attitudes within the three historically differentiated spheres of recognition. 
Table 1. Recognition and the Psychological Conditions for Exercising Autonomy

\begin{tabular}{|c|c|c|c|}
\hline $\begin{array}{l}\text { Enabled } \\
\text { autonomy } \\
\text { capacity }\end{array}$ & $\begin{array}{l}\text { Required } \\
\text { attitude } \\
\text { toward } \\
\text { oneself }\end{array}$ & $\begin{array}{l}\text { Empirically } \\
\text { necessary } \\
\text { recognitive } \\
\text { attitude by } \\
\text { others }\end{array}$ & $\begin{array}{l}\text { Form in which } \\
\text { recognitive } \\
\text { attitude is } \\
\text { manifest }\end{array}$ \\
\hline $\begin{array}{l}\text { Openness to } \\
\text { reasons deriving } \\
\text { from desires }\end{array}$ & $\begin{array}{l}\text { Basic } \\
\quad \text { Self-confidence }\end{array}$ & $\begin{array}{r}\text { Emotional } \\
\text { support }\end{array}$ & $\begin{array}{l}\text { Love and } \\
\text { friendship }\end{array}$ \\
\hline $\begin{array}{l}\text { Making } \\
\text { independent } \\
\text { judgements }\end{array}$ & Self-respect & $\begin{array}{r}\text { Cognitive } \\
\text { respect }\end{array}$ & $\begin{array}{l}\text { Granting equal } \\
\text { rights, } \\
\text { participation } \\
\text { in decision- } \\
\text { making }\end{array}$ \\
\hline $\begin{array}{l}\text { Adopting } \\
\text { identity-defining } \\
\text { long-term goals }\end{array}$ & Self-esteem & $\begin{array}{l}\text { Social } \\
\text { valuing }\end{array}$ & $\begin{array}{l}\text { Symbolic and } \\
\text { material } \\
\text { reward for } \\
\text { achievement }\end{array}$ \\
\hline
\end{tabular}

for exercising them causally depend on social interaction. It is time to point out that in fairness to traditional individualist conceptions, so far I have presented nothing that, say, Frankfurt or Mele could not accept and accommodate, with the possible exception of Fichte's view. This may sound surprising to some, but it is a straightforward consequence of the empirical nature of the claims made so far. Marilyn Friedman is perhaps the most forthright of all empirical intersubjectivists in acknowledging that her view of what constitutes autonomy is traditionally individualist. ${ }^{52}$ However, the same goes for Honneth. By emphasising the empirical and naturalistic character of his theory, he is committed to treating recognition by others as contributing merely causally to one's autonomy, by way of helping establish a positive practical self-relation. If this is all, there is a danger of false advertising when Honneth talks about "the profoundly intersubjective nature

${ }^{52}$ Marilyn Friedman, Autonomy, Gender, Politics, Oxford University Press, Oxford, 2003, p. 15. 
of autonomy". ${ }^{3}$ There is nothing the individualist need dispute. Gerald Dworkin, for example, encourages philosophers to suggest empirical hypotheses about "what psychological and social conditions are likely to promote the development and maintenance of autonomous individuals" ${ }^{54}$ Thus there seems to be no essential philosophical difference between weak intersubjectivism and traditional individualism, only a different focus of attention, and a reliance on empirical theories in the case of the former. Given that the ultimate aim of intersubjectivists is as a rule in political philosophy, this may not be so problematic, so long as the empirical theories hold water - why should it matter if something is conceptually or only causally necessary for autonomy, if you are designing institutions that promote autonomy?

This dialectical situation does, however, put a heavy burden of proof on empirical intersubjectivists who want to go beyond what traditional liberals already allow is needed for respecting autonomy. I want to finish this section by noting a few concerns about Honneth's empirical assumptions. First, the empirical results he appeals to do not rank particularly high on scientific standards. The psychological theories that Honneth spends most time discussing belong to the psychoanalytic tradition. To put it charitably, there is little hard evidence for claims made by psychoanalytic theorists, and yet equally few inhibitions in the way of making grand, implausible claims like the mother and child being initially "incapable of individually demarcating themselves from each other". ${ }^{55}$ The theories of Winnicott and Benjamin are highly speculative, arguably more so than the folk psychological hunches of philosophers, so there is scarce solid empirical support to be found in this direction. When it comes to self-respect and self-esteem, Honneth himself is content with appealing to our common experience. This is fine in itself, and the claims that he makes are by and large plausible. Insofar as they draw on commonsense folk psychological knowledge, however, they must be judged by commonsense criteria.

This brings us to the second main problem: when Honneth's claims are judged by the sort of commonsense criteria he avails himself of,

${ }^{53}$ Anderson and Honneth, "Autonomy, Vulnerability, Recognition, and Justice", p. 145 .

${ }_{54}$ Gerald Dworkin, Theory and Practice of Autonomy. Cambridge University Press, Cambridge, 1988, p. 162.

${ }^{55}$ Honneth, The Struggle for Recognition, p. 99. It does not seem at all plausible, for example, that a mother would be incapable of distinguishing between herself feeling hungry and the child feeling hungry. 
they turn out to be too weak to force a significant revision of liberalism. Basically, it is plausible that being recognised is empirically necessary for acquiring sufficient capacity to respect or esteem oneself. But once people have come to be able to respect and esteem themselves, misrecognition may simply lead them to resent those who do not respect or esteem them rather than prevent them from exercising their autonomy-constituting capacities. As Honneth himself acknowledges in the paper co-authored with Anderson, it is "psychologically possible to sustain a sense of self-worth in the face of denigrating and humiliating attitudes", though it is "harder to do so, and there are significant costs associated with having to shield oneself from these negative attitudes and having to find subcultures for support". ${ }^{56}$ What is more, there seem to be straightforward counter-examples to the recognitional view: it is surely not impossible that there could be self-respecting slaves who have never been respected by others, certainly not in terms of giving them rights. In light of such considerations, Diana Tietjens Meyers argues that " $[t]$ here are autonomous dissenters and revolutionaries and legions of individuals who autonomously craft private lives within the confines of oppressive regimes". ${ }^{57}$ If this is right, then it is certainly possible to be overcome psychological obstacles to exercising autonomy without being recognised at a given moment, even if it may indeed be harder.

\section{Recognition and Normative Competence}

The doubts I raised at the end of the previous section about the empirical validity of the recognitional view are far from decisive, and I will continue to assume that as a rule, recognition is needed to obtain the psychological conditions for the exercise of autonomy. However, there is another, more serious problem with Honneth's assumptions about autonomy-constituting capacities. Openness to one's desires and subsequent deliberation about them plays a major role in his view. However, recent discussions within action theory and metaethics strongly challenge this picture of desire and deliberation, providing support for a substantive conception of autonomy. Once we conceive

\footnotetext{
${ }^{56}$ Anderson and Honneth, "Autonomy, Vulnerability, Recognition, and Justice", p. 131.

${ }^{57}$ Meyers, 2000, p. 152. I do not, ultimately, accept Meyers' description of these people as autonomous; see section 5 .
} 
of autonomy-constituting capacities along substantivist lines with reasons-responsiveness as a central component, we must reformulate the details of the recognitional view accordingly, if it is to retain its plausibility in contemporary discussion.

\subsection{Desires, Reasons and Deliberation}

As we have seen, for Honneth the most basic form of recognition in the form of love and friendship enables one to access one's desires and feelings in deliberation, to treat them as reason-giving. The following passage sums up this view nicely: "[A]utonomous agents are ... open to those sources of identity and choice that underlie practical reasons, in the primitive and inchoate urges, impulses, longings, and despairings that can come to be transformed into reasons". ${ }^{58}$ The view presumes that first, (some) desires are reasons (or perhaps sources of reasons), second, we deliberate about our desires, and finally, desires and urges somehow express the authentic individuality of the agent. Each of these theses represents a problematic inward orientation at odds with Honneth's avowed departure from subject-centred philosophy.

To begin with the relationship between desires and reasons, few philosophers working in metaethics today would deny that most of our (normative) reasons for action, considerations that favour doing something or adopting an attitude, are desire-independent facts about the world, though some still fight a rearguard action of claiming that these facts owe their status as reasons for our desires. ${ }^{59}$ What reasons are there for me to sit outside and read? Why, the fact that the sun is shining, that it would be pleasant, that reading this book would be useful. No desires or beliefs feature in the list. The belief that the sun is shining, for example, would not be a reason for me to go out, since if it were false, it would not favour my doing so. ${ }^{60}$ However, is it not the case that the sunshine is a reason for me to go out because I want to sit in the sun

${ }_{58}$ Anderson and Honneth, "Autonomy, Vulnerability, Recognition, and Justice", p. 134. Compare Axel Honneth, 'Dezentrierte Autonomie. Moralphilosophische Konsequenzen aus der Subjektkritik'. In Honneth Das Andere der Gerechtigkeit. Suhrkamp, Frankfurt, 2000, p. 247.

${ }^{59}$ For an example of rear-guard Humeanism, see M. Schroeder, "The Scope of Instrumental Reason," Philosophical Perspectives, vol. 18, 2004, pp 337-364.

${ }^{60}$ To be sure, in exceptional cases beliefs - rather, believings - themselves can serve as reasons; in Dancy's example, the belief that a cliff is crumbly may be a reason not to climb it whether or not it is true, if it makes the agent nervous and so more likely to fall (J. Dancy, Practical Reality, Oxford, Oxford University Press, 2000, pp. 124-125). 
(the rearguard strategy I mentioned above)? No. First of all, I want to sit outside because I think I would enjoy it - the very fact that is the reason for me to go out is the reason why I want to do so in the first place. Second, we often have reasons to do things we do not want to do, even if we are fully informed about the situation; for example, the adolescent anorectic has a good reason to eat even if they do not want to. Third, if there were no reason for me to go out, my wanting to do so would not provide me with one. What Jonathan Dancy calls "the simple argument" is that if $\varphi$-ing is silly or just not very sensible, desiring to $\varphi$ does not make it any less silly or more sensible; nor does it give a reason to do something that subserves $\varphi$-ing. ${ }^{61} \mathrm{He}$ refines this by pointing out that generally, we desire to do something for a reason, because it would lead to or promote something of value. If the desire is based on a reason, desiring itself does not $a d d$ to the reasons. If, on the other hand, the desire is not based on a reason, we can have no reason not to abandon it. ${ }^{62}$

Since desires are not the source of our practical reasons, it is not surprising that they have at best a minor place in our practical reasoning and deliberation. Honneth, like Frankfurt and Korsgaard, ${ }^{63}$ seems to hold that we focus on what we want and feel when we reason practically; it is as if desires 'propose' certain courses of action, which we then reflectively endorse or reject. In this vein, Honneth talks about 'trusting' desires and 'engaging' with one's feelings, and about 'openness' to one's 'internal voices'. However, this argument skirts close to committing what Simon Blackburn terms "the fundamental mistake about deliberation". ${ }^{64}$ When I deliberate or reflect on whether to go to a concert or a football match, say, I do not, as it were, close my eyes and focus on how I feel when I think about the alternatives. ${ }^{65}$ Instead, I focus outward, on the features of the alternatives. What counts for or against an option is not that I want or do not want to take it, but whether or not it is worth taking because of its properties. ${ }^{66}$ Even if

\footnotetext{
${ }^{61}$ ibid., p. 32.

62 ibid., pp. 34-39.

${ }^{63}$ Frankfurt, 1988; C. Korsgaard, The Sources of Normativity, Cambridge, Cambridge University Press, 1996.

${ }^{64}$ S. Blackburn, Ruling Passions, Oxford, Clarendon Press, 1998, pp. 253-256.

${ }^{65} \mathrm{It}$ is notable that 'reflection' in the ordinary sense does not involve any kind of reflexive turning inward; one ought not let etymology mislead here. Other languages, such as Finnish, do not exhibit this misleading connection.

${ }^{66}$ Some of these properties may be response-dependent - maybe I decide against the concert because it would be boring - but these are still properties of the alternative choices, not psychological facts about me.
} 
I ask myself whether I really want to do something - a question that Meyers and Sandel, for example, see as central for autonomous agents $^{67}$ - all this amounts to is asking whether the course of action, by my lights, is really worth taking. ${ }^{68}$ In Gareth Evans's terms, selfknowledge is transparent with regard to our take on the world in non-pathological cases - to ask whether I believe that p, I consider whether $\mathrm{p}$ or not, looking out, not in. ${ }^{69}$ In short, we must reject any picture of autonomous deliberation according to which our desires or feelings are, as we might put it, deliberatively salient, except in exceptional cases.

The third and final problem with Honneth's account of basic selfconfidence concerns the status of "creative impulses" or "desires, impulses, fantasies, and other dimensions of subjectivity"70 as manifestations of spontaneous, creative agency - the Meadian 'I', as opposed to 'me', or the Freudian 'id." ${ }^{\text {'1 }}$ This kind of view can hardly help assuming that there is some pure, unspoiled inner core or self from which these 'creative impulses' stem, whereas in fact one need not worship at the altar of Michel Foucault to acknowledge that socialisation, cultural models and media images - not to mention biological facts - crucially shape our fantasies and unreflective urges. It is no surprise that fantasies can be boringly similar within cultures, and differ in predictable ways among them. Second, partly for this reason, control by urges, impulses, and the like is one of the paradigmatic contrasts with autonomy, as I noted in the first section. Insofar as they are not already reasons-responsive, it is quite unclear how the desires and urges could

${ }^{67}$ Diana Tietjens Meyers, Self, Society, and Personal Choice, Columbia University Press, New York, 1989; Sandel, 1998, p. 159.

${ }^{68}$ For a full argument, see A. Kauppinen, "Practical Reasoning and Self-Knowledge", paper presented at the Unity of Reason conference at The University of St. Andrews, June 20, 2005. See also R. Moran, Authority and Estrangement: An Essay on SelfKnowledge, Princeton, Princeton University Press, 2001; Watson, 1975, p. 30.

${ }^{69}$ G. Evans, The Varieties of Reference, Oxford, Clarendon Press, 1982, pp. 225-228. Evans' thesis is not, it must be emphasised, the Cartesian one that we are transparent to ourselves, but that insofar as we are not alienated from our beliefs (evaluative beliefs and consequent desires included, as I argue), questions about our own beliefs are answered from the first-person perspective by answering questions about facts, that is, the object of the belief. Precisely when there is a disconnection - we find ourselves believing or desiring something we do not take there to be any reason to believe or desire - some kind of remedial reflection and perhaps even therapy is needed, as Richard Moran argues (Moran, 2001).

${ }^{70}$ Anderson and Honneth, "Autonomy, Vulnerability, Recognition, and Justice", p. 134 .

${ }^{71}$ For the comparison between Mead and Freud here, see especially “Objektbeziehungen und postmoderne Identität”, pp. 148-149. 
be 'transformed into reasons' on which one acts autonomously. On the contrary, we act spontaneously precisely when we use our rational capacities that allow us to transcend both inner urges and socialisation.

\subsection{Autonomy and Normative Competence}

The evaluative capacity required for being held accountable and thus autonomous is not, then, one that has to do with one's desires, but with desire-independent reasons for action. In other words, hierarchical accounts of the sort Honneth relies on are out of the question. Evaluative beliefs are beliefs about the world, and deliberation is likewise oriented at potential courses of action and the value they bring about. As such, this is compatible with evaluativist as well as normative competence accounts of autonomy competency. However, I believe we have reason to prefer the latter. On normative competence accounts, it is not sufficient that our actions flow from our deep selves or strong evaluations, but those evaluations themselves have to be at least moderately responsive to the reasons that we have - reasons that may be personal (relative to one's personal history, commitments, capacities, pleasures, relationships, unique situation, and so $\mathrm{on}^{72}$ ), social, aesthetic, moral, or whatever. According to them, being autonomous implies that if I had a strong reason not to engage in the activities I do, I would be able to realise this and change my conception of what is worth doing. Thus false beliefs about the value of my central projects would undermine my autonomy. This view makes evaluative and factual mistakes symmetrical: just like I would not be self-governing with respect to an action if I chose it out of ignorance of fact (I thought it would lead to a desirable outcome, whereas in fact it was never going to), I would not be self-governing with respect to it if I chose it out of ignorance of value (I thought the outcome was desirable, whereas in fact it was nothing like that). While individual mistakes are compatible with autonomy on this account - so that people who wrong others or are just plain silly sometimes do not automatically lose autonomy systematic mistakes are not. ${ }^{73}$

${ }^{72}$ I emphasise this aspect, since it is particularly important in the case of autonomy to see that objective reasons can (and will) vary between individuals, even though they do not depend on their desires or beliefs.

${ }^{73}$ Fischer and Ravizza talk of "moderate reasons-responsiveness" to make it clear that perfect recognition and motivation are not necessary for agents to count as 
This view has several benefits. When we are responsive to reasons, our values are not hostage to mere chance or prevailing views; our preferences are not 'adaptive' in the sense in which those of a contended slave will be. ${ }^{74}$ Instead, we are able to revise them, even, as Susan Wolf puts it, correct or improve ourselves. ${ }^{75}$ To take a mundane example, suppose I am musically talented and would considerably enjoy playing an instrument. In this situation, it is plausible that I have a reason to take up playing music at least as a hobby. If I am not capable of recognising this, my choice about what to do in my free time will be less autonomous; it will be explained by such factors as peer pressure and cultural conventions. If my choice is, however, partly explained by my (genuine) recognition of what reasons I have, it will potentially transcend these other factors. It will shape an identity that is genuinely my own. Second, the normative competence approach preserves best the link between autonomy and responsibility, since it is not fair to hold responsible agents who are through no fault of their own incapable of recognising the difference between (morally, legally and otherwise) right and wrong. This is recognised in such legal conventions as the M'Naughten rule. ${ }^{76}$ Third, it also best explains the value of autonomy. Autonomy is valuable, since it leads us to valuable pursuits that we can experience as our own, thus contributing to our wellbeing. Choice that is not responsive to reasons may or may not be good for the agent; if it is valuable, it is not as valuable as reasons-responsive choice. ${ }^{77}$ Finally, and related to the previous point, from the inside, first-personal perspective, it matters greatly to us whether what we take to be valuable really is valuable, or whether it just seems so. As Charles Taylor puts it, "how can we deny that it makes a difference to the degree of freedom not only whether one of my basic purposes is frustrated by my own

responsible (Fischer \& Ravizza, 1998, pp. 41-46, 69-85). See also Pettit 2001, pp. 95-97 and Smith, 2003, for perspicuous presentations on this issue.

${ }^{74}$ For the notion of adaptive preferences, see J. Elster, Sour Grapes, Cambridge, Cambridge University Press, 1983.

${ }^{75}$ S. Wolf, "Sanity and the Metaphysics of Responsibility", 1987, reprinted in Watson, 2003, p. 385.

${ }^{76}$ As Susan Wolf puts it, according to the M'Naughten rule, a person is sane (responsible) "if (1) he knows what he is doing and (2) he knows that what he is doing is, as the case may be, right or wrong" (Wolf, 1987, p. 381).

77 See Joesph Raz, The Morality of Freedom, Clarendon Press, Oxford, 1986, pp. 390-395. Michael Smith formulates the connection between normative competence and the value of autonomy very strongly: "[W]e value agents ruling themselves to just the extent that, in so doing, they thereby manifest their capacity to get things right" (Smith, 2004). 
desires but also whether I have grievously misidentified this purpose?"78 If I discover that in doing what I really wanted I was chasing something quite worthless, I can quite intelligibly feel, that had I been in a better position to make autonomous choices, I might have been capable of recognising where the real reasons lay.

\subsection{Recognition and Reasons-Responsiveness}

Given that we are best off conceiving autonomy-constituting capacities in terms of reasons-responsiveness, how should we think of the selfrelations that make possible their exercise? Is it possible to reformulate the recognitional view so as to take this into account? In this section, I will briefly explore how this could be accomplished. Since desires play a central role in Honneth's account of self-confidence, I will focus on that - little reformulation is needed for the accounts of self-respect and self-esteem.

My suggestion is that we start from the idea that desires are responses to "appearances of the good", as Sergio Tenenbaum puts it, following the scholastics. ${ }^{79}$ What we trust when we have basic self-confidence, then, is that what appears to us as valuable or reasonable is such in reality - in particular, that what appears to us as a personal reason really is a reason that potentially grounds claims on others as well. For example, let us imagine that it seems to me there is good reason for me to take part in a demonstration against budget cuts for schools. My selfconfidence manifests itself in my taking this seeming seriously in deliberating about the issue. If I lacked self-confidence, I would dismiss this sense of things that I have and perhaps consider only reasons related to what my superiors might think about demonstrating. Reformulating the account in these terms preserves the connection to intersubjective recognition, since it is plausible that I learn to trust appearances of the good (as well as discriminate between mere seemings and epistemically valuable appearances) in the sort of early childhood interaction that Honneth talks about - from my perspective, what seems good to and for me really is good, since others are willing to take the trouble to bring it about. My pleasure and pain do not matter just to me, but to others as well. They do not merely push and pull

\footnotetext{
78 Taylor, Philosophy and the Human Sciences, p. 228.

79 See S. Tenenbaum (forthcoming), Appearances of the Good: An Essay on the Nature of Practical Reason, Cambridge, Cambridge University Press.
} 
me, but serve as sources of reasons, and as such ground claims on others.

We can also reformulate in less metaphorical terms the psychoanalytic insight that maturity is not just a matter of the ego controlling inner urges but "inner dialogue" in which desires have a speaking part. ${ }^{80}$ The insight here is that conscious, deliberative judgement does not necessarily represent one's perspective on an issue. It may itself be deformed by oppressive socialisation. Nomy Arpaly uses Huckleberry Finn as an example. ${ }^{81}$ Huck, who has been raised to think of 'niggers' as inferior, gets to know the slave Jim, helps him escape, and finds himself even apologising to him. At the level of reflective judgement, Huck believes he is acting wrongly in treating a slave as a full person, since this is the only position that he can articulate in the language available to him. He reproaches himself for having "the spunk of a rabbit", but cannot bring himself to turn Jim in. Yet it is clear in the context of the story that helping Jim reflects best his own, inchoate sense of what there is reason to do; as we might say, his authentic self is in control when he acts against his articulated judgement. This is manifest, for example, in his emotions when he considers the various alternatives. In such a situation, acting autonomously requires precisely going against one's judgement and instead listening and trusting one's affectively laden sense of things. Since this is always potentially the case, a rigid personality is harmful to autonomy; reasons-responsiveness manifests itself not only in judgement, but also in desire and emotion themselves.

\section{The Social Conditions of Exercising Autonomy}

The subjective experience of recognition is plausibly an empirically necessary internal or psychological (and thus indirectly intersubjective) condition for the exercise of autonomy competency, understood along the lines of a normative competence view. Are there any external or social necessary conditions for the exercise of autonomy though? How might we defend a strongly intersubjective conception that ties

\footnotetext{
${ }^{80}$ See, for example, Honneth, "Objektbeziehungen und postmoderne Identität", p. 159.

${ }^{81}$ Nomy Arpaly, Unprincipled Virtue, Oxford University Press, Oxford, 2003, pp. 9-10, 75, 78 .
} 
autonomy directly and constitutively to standing in certain kinds of relationships? I will make the case in the same Hegelian manner as Honneth does, by looking at cases in which autonomy is reduced simply in virtue of lack of such relationships and laying out what features they have in common. If it is the case that someone's autonomy can be diminished despite intact psychological capacities and practical selfrelations, having a certain social standing or status is itself constitutive of autonomy. On this view, there can be two psychologically identical agents, one of them autonomous, the other non-autonomous, in virtue of their different social relationships. ${ }^{82}$ To provide support for this, I will first present some test cases for which this strong thesis seems to hold. To assess these cases, we must bear in mind the theoretical role of personal autonomy as the kind of authentic self-determination that allows their lives to express the agent's practical identity and grounds the fairness of holding the agent fully accountable - praising or blaming her for them. This theoretical role connects autonomy to commonsense concepts, with regard to which we can regard our considered intuitions as authoritative. Is this kind of life a manifestation of the agent's deep commitments? Does she warrant blame for particular kinds of choices? If the intuitive answer is negative, the agent does not count as (fully) autonomous - - she may have the capacities, but if unable to exercise them, her autonomy remains a potentiality.

Here are four test cases for the strongly intersubjective thesis:

Case 1. Jim is a slave. He grew up in freedom, and is as capable of recognising and assessing reasons for action as anyone else, and suffers from no volitional or motivational defects. Though he loathes his circumstances, he respects himself - indeed, that is one reason why he so loathes his circumstances. He takes care of his heavy duties well, and has no problem with his self-esteem; he knows he is capable of much. It is no surprise, then, that Jim is capable of forming a conception of good life for himself within the realities of his society, and a corresponding life-plan. But he has no opportunity to pursue it, since his master has the coercive power to impose his own plans on Jim. And even if Jim's plan were to fall within the limits that his master would tolerate, the master would remain in a position to undo it on an arbitrary whim, regardless of Jim's own judgement.

Case 2. Z lives in a state run on fundamentalist religious principles. Like Jim, she has full autonomy competency, respects herself, and trusts in the

${ }^{82}$ As Marina Oshana notes in "Personal Autonomy and Society", The Journal of Social Philosophy 29 (1), 1998, pp. 81-102. 
validity of her emotions and desires in revealing what is good for her. However, she is sexually aroused only by women. In her society homosexual conduct is legally, socially and culturally discouraged. Though her sexual orientation makes it impossible for her to adopt the kind of identity that there is available for women in her culture - built as it is around marriage and motherhood - there does not exist an alternative practice of lesbian relationships that would provide a social matrix of significance within which she could develop an identity she is at home with, nor does she have the opportunity to participate in the creation of such a practice.

Case 3. Billy Bob is a policeman. He has the same competencies, skills and attitudes toward the self as Jim and Z. However, due to a combination of factors including the nature of his work, genetic predispositions and ignorance, he has gained 145 kilograms by his early 30 s, quite a lot for such a short man. He was never any good at developing a rapport with women, and has not had a relationship for longer than anyone can remember. All he wants from life is to find someone special and settle down for good.

Case 4. Despite growing up in a broken family, Tammy has her rational capacities and self-confidence intact. To make ends meet and pay for the trailer where she lives with her binge-drinking boyfriend, she works long hours cleaning and scrubbing the houses of the rich. Like her coworkers, she suffers from chronic back pain, cramps and arthritic attacks. Still, the company that pays her minimum wage boasts in its brochure: "We clean floors the old-fashioned way - on our hands and knees", so she has to assume that humiliating position in front of the upper-class housewives who scrutinise and point out every speck of dirt she fails to notice. This is not her idea of a good life, but it is the best she can get with the cards she was dealt and the rules that were handed down. ${ }^{83}$

In each of the cases, the subject is capable of being autonomous, both in the sense of having the necessary rational and motivational capacities and meeting the psychological conditions for their exercise. Yet they are in different ways prevented from exercising their autonomy by their social environments, and therefore are not autonomous. They are not in control of their lives in the sense that matters. It may be unlikely that they still respect, esteem and trust themselves, but it does happen and it is not all that rare - people do adjust their expectations to their chances, and there may be systematic indoctrination and ideology

${ }^{83}$ This case is based on the real-life experiences of minimum-wage workers studied by Barbara Ehrenreich (Nickel and Dimed. On (Not) Getting By in America, New York, Henry Holt, 2001, ch. 2). 
involved. ${ }^{84}$ A positive relation to self that is rooted in false beliefs about one's standing in the eyes of others is no guarantee of autonomy.

\subsection{Lacking Opportunities}

The first three cases are examples of three dimensions of objective misrecognition. The first I will call the dimension of (external) domination. Domination in this sense occurs when the agent is coerced actually or virtually by an agent or institution that gives no weight to their reasons - that is, is vulnerable to interference that is not in their avowed or avowable interests. As Philip Pettit puts it, to be in this position of relative powerlessness it is sufficient that one could be coerced without impunity. ${ }^{85}$ This is the case when one cannot effectively enforce one's claim to be treated as a person capable of assessing and adopting longterm goals. As a consequence, the opportunity to plan ahead or carry out one's rational life-plan is not available to the dominated agent. She does not have the necessary legal, social, or cultural standing for this, nor does she have the opportunity to challenge the rules of the practice that relegates her own views to irrelevance. Slaves are the most salient examples of this form of misrecognition, but as Pettit notes, in many cultures subjugated wives, for example, are not in a much better position. ${ }^{86}$ Their authorship in their lives is limited to trivial decisions, and they cannot be held responsible for failing to develop their talents, for example. ${ }^{87}$ Prisoners, by contrast, may be autonomous - though they are coerced - if that takes place as a result of their past autonomous action in violation of laws that they (have reason to) at least tacitly

${ }^{84}$ For the general phenomenon of 'making a virtue out of necessity', see, for example, P. Bourdieu, The Logic of Practice, Stanford, Stanford University Press, 1990, p. 54.

${ }_{85}$ Philip Pettit, A Theory of Freedom, Polity Press, Cambridge, 2001, pp. 78-79, 137-138. For important qualifications see also H. S. Richardson, Democratic Autonomy. Public Reasoning about the Ends of Policy, Oxford, Oxford University Press, 2002, pp. 28-36.

${ }_{86}$ Pettit, $A$ Theory of Freedom, p. 78. For the psychological effects of domination, see Friedman, 2005.

${ }^{87}$ Someone like Meyers might ask: what about Spartacus, then? Did he not act autonomously when he rose to rebellion against his masters? Well, he certainly did exercise his power of judgement, but at the end of the day, he was killed for it. He did not have the opportunity to direct the course of his life; the social circumstances in which he found himself did not allow him to express his authentic self in his actions. So even if the particular action and desire of rebelling were autonomous, he himself as an agent or a person was not. 
accept, punishment is precisely what it takes to treat them as rational decision-makers. ${ }^{88}$

The second dimension of misrecognition is that of marginalisation of identities. Marginalisation either rules out or makes it harder for one to live the sort of life one has chosen, or perhaps just gravitated toward, for good reasons. This is because most, if not all, identitydefining projects or 'comprehensive goals' (Joseph Raz) that give direction to one's life are embedded in broader social practices or 'social forms. ${ }^{89}$ Take careers: one of Raz's examples is being a doctor, which is not just a matter of having skills to cure people but also involves "general recognition of a medical practice, its social organization, its status in society, its conventions about which matters are addressed to doctors and which not ... and its conventions about the suitable relations between doctors and their patients". ${ }^{90}$ It is not just that it is hard to value oneself as a doctor in such a society, as Honneth would allow; it is simply not possible to $b e$ one. The same goes for other kinds of identities that may seem natural. As Foucault so forcefully reminded us, a person who has sex with someone with similar genitals is not thereby a homosexual; there is a world of difference in the significance of sexual acts between men in ancient Greece and in nineteenth-century Germany, France and Britain, where 'the homosexual' with "a past, a history and an adolescence, a personality, a life style; also a morphology, with an indiscreet anatomy and possibly a mystical physiology"91 was born. In this sense, homosexuality is entirely unmysteriously and uncontroversially a social construction. Labelling someone a 'homosexual, often a highly charged term, may be an act of repression or a prelude to one, but as Foucault himself hints, the existence of such a classification also provides materials for constructing new possibilities

\footnotetext{
${ }_{88}$ As Hegel puts it, in being punished, the criminal is "honoured as a rational being" (Philosophy of Right, \$100R).

${ }_{89} \mathrm{Raz}$ prefers to talk of social forms consisting of "shared beliefs, folklore, high culture, collectively shared metaphors and imagination, and so on" (Joseph Raz, The Morality of Freedom, Clarendon Press, Oxford, 1986, p. 311) rather than practices, since he finds the latter term only connotes behaviour. When I talk of practices, however, I mean it in a broader sense that includes several of the Razian elements.

${ }_{90}$ Joseph Raz, The Morality of Freedom, Clarendon Press, Oxford, 1986, p. 311. See also Raz, Ethics in the Public Domain, Oxford University Press, Oxford, 1994, pp. 106-107.

${ }_{91}$ M. Foucault, (1978), The History of Sexuality, trans. R. Hurley, vol. 1, New York, Pantheon, 1980, p. 43.
} 
of self-expression, as shown by contemporary gay identities and the subcultures they are embedded in. In short, the social practices form a matrix of significance that is necessary for individuals to adopt meaningful life-plans, to exercise non-trivial reasoned choice. These practices are, obviously, contingent, historical and mutable; new meanings, opportunities and identities are constantly being born, old ones reinforced and reinvented. No particular opportunity may be necessary for autonomy as such, but legal, social or cultural prejudices that marginalise, stigmatise or penalise the practices that nourish certain identities diminish the autonomy of those individuals who could authentically express themselves only (or best) within them. Since this is the case even when the individuals escape psychological injury, like $\mathrm{Z}$ in our example, the harm to autonomy is a matter of objective social relations.

The third dimension of objective misrecognition I call emotional exclusion. If domination limits one's opportunities to realise one's plans in general and marginalisation limits one's opportunities to adopt particular identity-defining projects, emotional exclusion limits one's opportunity to form personal relationships. It is perhaps conceivable that there could be a human being who would have the capacity to make choices about one's life in response to reasons and would still not seek to engage in any close relationships, but it is doubtful any such person has actually existed..$^{92}$ For real people, pursuing and maintaining relationships to family, friends and lovers is an essential component of autonomous life. Correspondingly, their unavailability compromises the exercise of autonomy. Clearly, this is not much of a complaint when one gets turned down by someone one is attracted to, or never receives the invitation to cousin Agatha's wedding. For emotional exclusion to reduce autonomy, it must be a matter of systematic cultural value patterns that condemn people with certain qualities to a life of loneliness and detachment regardless of their contrary efforts.

It is no coincidence that these forms of objective misrecognition roughly coincide with the three dimensions of the subjective experience of recognition articulated by Honneth. Awareness of domination and lack of self-respect, awareness of marginalisation and lack of

92 There are people who shirk relationships, of course, but this is very likely the case because of a failure to appreciate the reasons provided by their importance to personal wellbeing (psychopaths), or psychological inhibitions and injuries (timidity, incapacity to love due to child abuse, and so on). 
self-esteem, and awareness of emotional exclusion and lack of basic self-confidence surely go together, empirically speaking. As I have argued, however, objective misrecognition with respect to power, identity or relationships by itself limits one's opportunity to lead a life of authentic self-determination, regardless of one's attitudes toward oneself.

Objective recognition, however, does not exhaust the social conditions for the exercise of autonomy. Lack of competitive material resources resulting from economic exploitation is an independent constraint on the exercise of autonomy. ${ }^{93}$ (I emphasise the competitive aspect, since for success in many pursuits, it is one's relative rather than absolute resources that count. ${ }^{94}$ ) As the situation of the cleaning woman in Case 4 shows, working for less than a living wage is apt to render one dependent on one's employer or one's family, leaving little room for significant autonomous choice. This hardly needs much argument. We can see this as a social condition of autonomy when we remember that the rules and principles of economic reward are legal, social and cultural in nature. There is nothing natural about bargaining situations that pin workers against employers separately rather than as a group, or inheritance laws that allow for accumulation of advantage from generation to generation. It is these rules rather than individual economic decisions made within them that may restrict the availability of resources in a way that threatens the exercise of personal autonomy. Though economic exploitation often goes together with domination or marginalisation, it is still conceptually distinct, as Nancy Fraser stresses. ${ }^{95}$ White, well-educated and self-respecting men in recognised professions can yet be exploited by option-hungry management in the ruthless environment of predatory capitalism.

\subsection{Being at Home in the Social World}

I have defined both objective recognition and competitive resources terms of availability of a guaranteed chance to realise life-plans, live

${ }^{93}$ I use the term 'exploitation' in a broader sense than Marxists, to refer to any situation in which one is rendered at the mercy of others as a result of lack of material resources.

${ }_{94}$ For an impassionate argument for the moral importance of positional goods and the corresponding value of equality by itself, see B. Barry, Why Social Justice Matters, Cambridge, Polity Press, 2005.

${ }_{95}$ Fraser and Honneth, Redistribution or Recognition?, pp. 16-22. 
out identities, participate in relationships, and make an independent living. But what does availability mean here? It obviously cannot mean getting what one wants whenever one wants it. Promoting someone's autonomy does not require somehow providing her with magical or dictatorial control of her life. ${ }^{96}$ Nor should we rush to moralise autonomy, so that one could be autonomous only if one respects the like autonomy of others - it is possible to be personally autonomous and immoral, though normative competence involves some degree of sensitivity to the reasons of others. Instead, I have implicitly interpreted availability democratically, in terms of the following three conditions. The goods required for the exercise of autonomy are available to an agent if and only if:

(a) the rules of the relevant practices reflect the agent's (personal and other) reasons

(b) the agent has the opportunity to ensure that (a) holds

(c) the agent cognitively and emotionally accepts that (a) holds (the subjective experience of recognition)

The first condition is that the rules of the relevant practice must reflect the agent's reasons. This is obviously a matter of degree, as it should be, since autonomy is a matter of degree. When the (usually implicit) rules of a social practice take into account an individual agent's reasons, she has the opportunity to exercise her capacity to be responsive to these reasons in making her choices. For example, if $Z$ derives sexual pleasure from relations with other women, $\mathrm{Z}$ has a reason to explore such relations, and her autonomy will be reduced if the sexual mores of her social environment reflect only men's interest in their pleasure and a social interest in reproduction. The second, participation condition, stresses that it cannot be a coincidence that the rules incorporate the agent's reasons. If they are subject to change by the arbitrary will of others, opportunities are not available in the sense required for longterm projects. What it means for an individual's voice to be heard varies considerably by case - it is one thing to have input to legislative decision-making and another to make a difference to diffuse cultural

${ }^{96}$ As Michael Hardimon puts it in Hegelian terms (see below), "[T]o say that the social world is a home is not to say that it meets our each and every wish. It is, rather, to say that there is no significant objective dimension along which we are split from it" (Hardimon, "The Project of Reconciliation: Hegel's Social Philosophy," Philosophy and Public Affairs, vol. 21, no. 2, 1992, p. 187) 
value patterns. Little can be said a priori about this. The final, subjective acceptance condition, points back to the experience of recognition. The agent must be confident that the rules take her reasons into account to be able rely on them and participate wholeheartedly in the practice. $^{97}$

The conditions (a) to (c) delineate in general terms what counts as a fair chance with respect to the various analytically distinct goods needed to exercise autonomy: social power, cultural resources, personal relationships and economic resources. ${ }^{98}$ The difference between objective recognition and misrecognition, as well as competitive and insufficient material resources, is the difference between meeting them and failing to meet them with respect to these goods. Since the conditions incorporate political participation, broadly understood, it cannot be said in advance where the lines are to be drawn in particular cases. However, we can say that if (a) to (c) are fulfilled for each practice within which one acts and lives, the objective social conditions for exercising autonomy are met and the agent is aware of this; in short, the she is at home in her social world, to use the Hegelian expression. She is neither objectively nor subjectively alienated from her surroundings. I will summarise these results in a table and then examine briefly the Hegelian background of this type of theory.

\subsection{Related Views}

The historical model for this type of account is Hegel's Philosophy of Right, which can be read as an extended argument for the social and institutional preconditions of actualising individual freedom, as Honneth suggests in his Suffering from Indeterminacy. Hegel begins with a commonsense conception of freedom: to be free is to be unconstrained or unlimited. But what is it to be unconstrained? Hegel mocks those who equate lack of constraint with the mere ability to step back from immediate impulses; such abstract conception of freedom is a recipe for inaction or blind fury of levelling all the distinctions

\footnotetext{
${ }^{97}$ Since the rules are by nature general, they will also reflect the reasons of others involved in the practice; consequently, in accepting them and acting accordingly, one recognises those others in the relevant capacity. The recognition must thus be mutual.

${ }_{98}$ Having a fair chance does not entail being successful. Thus, given these conditions, it is possible for an agent to fail to get what they want even though the kind of opportunities autonomy requires are available to them. This is why being fired or imprisoned or rejected does not in itself reduce autonomy.
} 
Table 2. The Social Conditions of Exercising Autonomy

\begin{tabular}{|c|c|c|c|}
\hline $\begin{array}{l}\text { Enabled } \\
\text { autonomy } \\
\text { capacity }\end{array}$ & $\begin{array}{l}\text { Required } \\
\text { opportunity }\end{array}$ & $\begin{array}{l}\text { Lack of } \\
\text { opportunity } \\
\text { amounts to }\end{array}$ & $\begin{array}{l}\text { Psychological } \\
\text { attitude } \\
\text { corresponding } \\
\text { to objective } \\
\text { recognition } \\
\text { (see table 3) }\end{array}$ \\
\hline $\begin{array}{l}\text { Acting on reasons } \\
\text { deriving from } \\
\text { emotional needs }\end{array}$ & $\begin{array}{l}\text { Access to personal } \\
\text { relationships }\end{array}$ & $\begin{array}{l}\text { Emotional } \\
\text { exclusion }\end{array}$ & $\begin{array}{l}\text { Basic self- } \\
\quad \text { confidence }\end{array}$ \\
\hline $\begin{array}{l}\text { Acting on } \\
\text { independent } \\
\text { judgements }\end{array}$ & $\begin{array}{l}\text { Access to social } \\
\text { practices } \\
\text { whose rules } \\
\text { guarantee } \\
\text { control over } \\
\text { life-plans }\end{array}$ & Domination & Self-respect \\
\hline $\begin{array}{l}\text { Realising } \\
\text { identity- } \\
\text { defining } \\
\text { long-term } \\
\text { goals }\end{array}$ & $\begin{array}{l}\text { Access to } \\
\text { practices } \\
\text { within which } \\
\text { comprehensive } \\
\text { goals acquire } \\
\text { significance }\end{array}$ & $\begin{array}{l}\text { Margina- } \\
\text { lisation }\end{array}$ & Self-esteem \\
\hline All of the above & $\begin{array}{l}\text { Access to compe- } \\
\text { titive material } \\
\text { resources }\end{array}$ & $\begin{array}{l}\text { Exploitation } \\
\quad \text { (economic } \\
\text { domination) }\end{array}$ & $\begin{array}{l}\text { Any or none } \\
\text { of the above }\end{array}$ \\
\hline
\end{tabular}

between people. ${ }^{99}$ To refuse to will anything particular is not to will at all, so talk of free will here must be empty - though the ability to abstract from particular contents is indeed an essential component of free will, since it is required to transcend determination by arbitrary, contingent desires and drives. Freedom that is worth its name must be concrete, it must be manifest in particular choices and actualised in the objective world. This requires, first, settling on a determinate content of the will (forming a particular intention) and, second, carrying out

${ }^{99}$ Hegel, Philosophy of Right, $\$ 5$. 
this intention through action (realising the end one has set for oneself). Both steps necessarily bring in limitations to abstract freedom: to settle on a goal means ruling out other goals, and action always takes place in a social and institutional context that allows some kinds of behaviour and rules out other kinds. Hegel's insight is that not all kinds of limitation have the same status: as long as one is (rationally) at home' (bei sich) with the limitation - as long as one identifies with one's goal and the normative framework within which one operates - one is not constrained by it, but quite the opposite; the limitations are an expression of one's self. His example of this is friendship and love, within which we "willingly limit ourselves with reference to an other, even while knowing ourselves in this limitation as ourselves". ${ }^{100}$ To be free, in other words, is to be constrained only by what one identifies with good reason, so that one is after all not determined by something external to oneself. ${ }^{101}$ It is to be reconciled with one's social environment. As Michael Hardimon stresses, for Hegel, this involves subjective acceptance of the practices and their being worthy of it - that is, in terms that I have used, the subjective experience of recognition and the objective fact of recognition. ${ }^{102}$ Given the conflicts of interest involved in modern social practices like the market and party politics, it may not be obvious (even when it is the case) that the normative framework expresses their values and takes into account both their individual and communal needs, thus enabling rather than restricting freedom. In these cases, it is a task of philosophy to help people see this - to see the rational in the real, as Hegel famously (or notoriously) put it. However, though Hegel's own inclinations are perhaps conservative, nothing in his view precludes the possibility of criticising a social arrangement that does, in fact, objectively alienate some of those affected by it by making it difficult or impossible for them to exercise their autonomy within it - quite the contrary. At this level of abstraction, at least, the model presented here is clearly Hegelian in spirit. ${ }^{103}$

${ }^{100}$ Hegel, Philosophy of Right, $\$ 7 \mathrm{Z}$.

101 Compare Hegel, Philosophy of Right, $\$ 23$ : “Only in this freedom is the will completely with itself, because it has reference to nothing but itself, so that every relationship of dependence on something other is thereby eliminated".

${ }_{102}$ Hardimon, "The Project of Reconciliation: Hegel's Social Philosophy", pp. 173-174. As he sums up the view later, it must be the case both that the social world is a home and that people grasp this, feel at home within it, and accept and affirm the social world (Hardimon, 1992, p. 181).

${ }^{103}$ I have not in any way tried to mirror the complexity of Hegel's tripartite account of abstract right, morality, and (itself internally complex) ethical life, nor have 
In terms of contemporary debates, a strongly intersubjective account of autonomy in a Hegelian spirit amounts to an Aufhebung of the dispute between Honneth and Nancy Fraser. I have argued that Fraser is correct in separating analytically the wrongs of economic maldistribution from those of recognition. In arguing for the independent importance of objective recognition in addition to subjective experience of recognition, I have also in effect subscribed to what Fraser calls a "status model of recognition", which construes recognition as a matter of institutionalised patterns of cultural value that enable one to participate as a peer in social life. ${ }^{104}$ From the Hegelian as well as liberal perspective, however, Fraser makes a mistake in displacing autonomy as the fundamental deontological normative notion in favour of what she calls "parity of participation", according to which "justice requires social arrangements that permit all (adult) members of society to interact with one another as peers" ${ }^{105}$ The Hegelian view, by contrast, sees access to participation in social life as normatively central because and to the extent that it is necessary for exercising autonomy. If we understand Honneth's concept of self-realisation to refer to exercising autonomy, we will thus side with Honneth on the issue of normative foundations. Indeed, it is difficult to see how one could answer the question of why participatory parity is valuable, if not by reference to the value of autonomy. No wonder Fraser avoids raising the question. ${ }^{106}$

Another advantage of the Hegelian view is that it recognises and incorporates not only the objective but also the psychological conditions for exercising autonomy. Neither Fraser nor Honneth seem to

I followed the principles of composition derived from his logic. By beginning my account of objective conditions from the various capacities whose exercise they enable, I have naturally ended up with a different classification than Hegel's, which is rather based on the various social spheres within which autonomy is exercised: family, civil society and the state. The capacities I discuss are exercised within each, though it may be true that there is a rough correlation between forms and spheres of recognition (that is, love and family, esteem and civil society, respect and state).

${ }^{104}$ Fraser and Honneth, Redistribution or Recognition?, pp. 28-33 and passim. Fraser's talk of cultural value patterns fits best with my account of the dimensions of non-marginalisation and non-exclusion.

${ }^{105}$ Fraser and Honneth, Redistribution or Recognition?, p. 36.

106 I thus concur with Honneth when he says of Fraser that, "there is something inherently arbitrary about her idea of participatory parity" (Fraser and Honneth, Redistribution or Recognition?, p. 179) and subscribe to what he calls "teleological liberalism" (p. 178). 
realise that the status and psychological experience models of recognition are complementary rather than mutually exclusive. Again, the former lays out (part of) the social conditions for exercising autonomy, while the latter involves empirically important social-psychological conditions for the same. Both social status and positive psychological self-relation are necessary for exercising autonomy, as I have argued. To be sure, Honneth's position is not as clear-cut as Fraser's rejection of psychological considerations. After all, the subtitle of his Suffering from Indeterminacy is "an attempt at a reactualisation of Hegel's Philosophy of Right", and he clearly recognises the objective and institutional character of Hegel's conditions for autonomy. Still, from his exposition, it is hard to tell which aspects of his Hegel exegesis Honneth actually endorses, and he sometimes adds a reference to how recognition enables the subject to see or experience him or herself as free, suggesting that in his interpretation the importance of recognition to autonomy is mediated by experience after all. ${ }^{107}$ Both The Struggle for Recognition and his contributions to Redistribution or Recognition? are unambiguously psychologistic. For example, in his response to Fraser he claims that we are interested in a just social order because "it is only under these conditions that subjects can attain the most undamaged possible self-relation, and thus individual autonomy"108 and that the "insufficiencies and deficits" of forms of mutual recognition are "always tied to feelings of misrecognition". ${ }^{109}$ Thus it is fairly safe to conclude that both Honneth and Fraser have a one-sided understanding of the double contribution of recognition to making possible the exercise of autonomy.

\section{Conclusion: Toward a Hegelian Liberalism}

In this essay, I have been exploring various conceptions of autonomy and assessing them against what I take to be the widely accepted theoretical role the concept has, finding that effective autonomy has three kinds of social or intersubjective conditions. The core of the concept is authentic self-determination. Authentically self-determining agents

\footnotetext{
107 See for example Axel Honneth, Leiden an Unbestimmtheit. Eine Reaktualisierung der Hegelschen Rechtsphilosophie, Philipp Reclam, Stuttgart, 2001, pp. 31, 80-81.

${ }_{108}$ Fraser and Honneth, Redistribution or Recognition?, pp. 258-259.

109 Fraser and Honneth, Redistribution or Recognition?, p. 245 (my emphasis).
} 
are fully accountable for their life choices and deserve to be rewarded and punished accordingly. This accountability requires that the agents are at least moderately responsive to desire-independent reasons and so capable of standing back from their immediate inclinations and assessing situations in light of standards that are not merely passed on through socialisation. I have defended this normative competence view as the best account of individual autonomy-constituting capacities. However, I have also laid out three ways in which the acquisition and effective exercise of these capacities, and so being autonomous, depends on a suitable social environment. First, we become autonomous only through being taken care of within an autonomysupporting culture. Roughly, we learn to understand and recognise reasons that go beyond biological needs in and through the process of initiation into language that involves qualitative distinctions of value. We gain a capacity to imagine living differently by learning about particular ways of life that are concretely realised in our culture or in the past, and learn to control our behaviour accordingly through internalising demands made, to begin with, by concrete, loving authority figures. Second, as a matter of fact and for the most part, we come to meet the psychological conditions for exercising autonomy (or second-order psychological capacities for autonomy) like self-confidence, selfrespect and self-esteem only through the experience of being recognised by others, in the context of the family, civil society, and the legal and political system. And third, even if we have both kinds of psychological capacities, we are still not able to lead an autonomous life unless the structure of our social environment meets the directly social conditions for exercising autonomy. We must be objectively recognised so that the rules of the relevant social practices do not deny us the opportunity to participate in personal relationships, pursue valuable comprehensive goals in a context within which they are meaningful, and enjoy guaranteed control over our plans of life. We must also enjoy sufficient competitive material resources, lest the opportunities opened by objective recognition remain meaningless. In each case, it does not suffice that the rules of the practices are accidentally responsive to our personal reasons; full exercise of autonomy requires that we have a voice in defining what being autonomous amounts to in our particular historical and cultural situation. A social world that meets all these conditions is a 'home' in the Hegelian sense, and insofar as we are also aware that it is such, we are at home within it, and so free and autonomous. It is unlikely, of course, that all these conditions are ever 
fully met. However, they, like autonomy itself, are a matter of degree, and we can be confident that most adults in contemporary Western societies meet them to a sufficient extent to be fit to be held responsible for their life choices, so the view does not set the bar for autonomy too high. In addition, it helps make sense of locally reduced responsibility. When either the psychological or directly social conditions for exercise are impaired with regard to a certain set of options, we are and should be reluctant to place blame on people for their failures in that regard.

While each of these intersubjective conceptions of autonomy has been addressed in the past, a systematic, comprehensive synthesis has so far been lacking. All that remains is to sketch how such a conception could be normatively fruitful as an internal critique of contemporary liberalism and liberal democracy. In doing so, I will adopt as a starting point a generic form of liberalism characterised by three basic principles. First, basic liberties are to be guaranteed to everyone by granting rights that trump utilitarian considerations of maximising general welfare. Second, the state is to be maximally neutral between competing rights-respecting conceptions of the good. And finally, distributive inequalities are acceptable so long as they are consistent with fair equality of opportunity, so that the resulting distribution is choicesensitive but endowment-insensitive. These principles concretise the goal of equally respecting each citizen as a person capable of forming and pursuing a conception of good and taking responsibility for her choices - in other words, respecting, protecting and promoting everyone's autonomy. That is why they are justifiable to everyone in a pluralistic society where there is no single model of the good life, as long as they are reasonable enough not to want to impose such burdens on others that they would not themselves accept. I will assume that this generic model captures the central ideas of such paradigmatic (nonutilitarian) liberals as Rawls, Dworkin, Kymlicka and Scanlon, though each develops and justifies his view in different ways.

The question then is whether individual rights, state neutrality and equal opportunity suffice to respect autonomy in light of its threefold social conditions. The issues that Hegelian liberalism raises are for the most part familiar from earlier debates around the challenges to standard liberalism - the hope is simply that the systematic framework allows a more perspicuous view and perhaps helps with their resolution. For example, as we have seen, communitarians, recognition theorists and perfectionists each argue that the existence of a plurality of valuable and valued ways of living embedded in cultural practices is 
necessary for autonomy. Taking a closer look though, communitarians like Taylor emphasise its importance for developing a capacity to make choices; recognition theorists like Honneth stress its role in acquiring and maintaining self-esteem; and perfectionists like Raz point out that it is necessary for exercising autonomy. These are very different arguments that rely on different kinds of evidence and have potentially different implications for autonomy-respecting policies, though there is naturally a significant degree of overlap. To mount an effective challenge to liberal assumptions, it is essential to have a clear view of these differences and the sort of conditions of autonomy they appeal to. Here, my goal is simply to indicate some directions for future research and possible liberal lines of response.

To begin with the development of first-order capacities, several of the empirical intersubjective requirements concern caring parentchild relationships. Thus they fall on the 'private' side of the public/ private distinction, and so, in some traditional liberal views, beyond the reach of justice. Insofar as respecting autonomy as an issue of justice, however, this means there is a potential conflict between the child's rights to the conditions of autonomy and the parents' rights to privacy and continuing a culture across generations. The parents' rights and pragmatic considerations speak against any direct legal regulation, which would no doubt be counterproductive within the sensitive family dynamic. However, acknowledging the child's interest provides an autonomy-based argument for non-intrusive, indirect measures, such as paid maternity and paternity leaves, free child-care classes and packages, well-trained and well-paid kindergarten teachers in public services, and pluralistic educational materials. ${ }^{110}$

What about the psychological conditions for the exercise of autonomy and their intersubjective requirements? Anderson and Honneth claim that accepting the recognitional view signals a "need for significant revisions to commitments of (Rawlsian) liberalism". ${ }^{111}$ Their main arguments seem to boil down to the following: rights are not sufficient

110 None of these means really addresses the need for loving parent-child relationships, and there is obviously little one can do to further them. However, since the emotional quality is essential for autonomy - including the psychological conditions for its exercise, as Honneth stresses - there is also a further autonomy-based argument for making available remedial means, such as therapy, for those who have been injured in this respect.

111 Anderson and Honneth, "Autonomy, Vulnerability, Recognition, and Justice", p. 142 . 
to guarantee psychological conditions for exercising autonomy, since legally enforced esteem and love are not only absurd but also positively useless for developing self-trust, and correspondingly "parties in the original position need much better understanding of these conditions for acquiring self-respect and self-esteem than Rawls equips them with". ${ }^{112}$ More broadly, they suggest a shift of focus from distributive to recognitional concerns. There are only scattered hints in Honneth's work for what this might mean in practice and how it would go beyond the sort of legal equality that liberals of all stripes should be willing to extend to everyone. He does suggest, however, that progress in the sphere of love might amount to "a step-by-step elimination of roleclichés, stereotypes, and cultural ascriptions that structurally impede adaptation to others' needs" and that in the case of social esteem it would involve "radically scrutinizing the cultural constructions that, in the industrial-capitalist past, saw to it that only a small circle of activities were distinguished as 'gainful employment' ". ${ }^{113}$ Thus it seems that there is no actual conflict with basic liberal tenets of rights and neutrality, but rather an emphasis on the need to supplement state action with cultural change, for which the recognition view offers evaluative criteria that are absent from liberalism.

Finally, the social conditions for exercising autonomy are already a battleground between liberals, on the one hand, and perfectionists, republicans, communitarians and deliberative democrats on the other, even if not always under that heading. Liberal egalitarians do naturally address domination and exploitation by insisting on civil and political

112 Anderson and Honneth, "Autonomy, Vulnerability, Recognition, and Justice", p. 143. It must be noted that Anderson and Honneth seriously misconstrue Rawls" 'original position' behind the veil of ignorance in their critique when they claim that according to him, participants "should not have knowledge of what people in the society are like, except the most basic features of their instrumental rationality" (Anderson and Honneth, "Autonomy, Vulnerability, Recognition, and Justice", pp. 141-142). On the contrary, Rawls argues that the parties know, among other things, "the laws of human psychology", and indeed "whatever general facts affect the choice of principles of justice" (Rawls, 1971, p. 137). Rawls himself goes on to give an example in which knowledge of moral psychology makes a difference to the principles adopted. Importantly, parties in the original position also have conception of primary goods, the kind of things that are useful or needed for any rational plan of life, and these include self-respect, "perhaps the most important primary good" (Rawls, 1971, p. 440). What the parties do not know is their own position in the society they are designing and the particular conception of the good they will have.

${ }_{113}$ Fraser and Honneth, Redistribution or Recognition?, p. 188. The latter argument relies at least in part on the mistaken view that economic compensation is rooted in cultural valuation. 
rights and fair equality of opportunity. Both republicans and deliberative democrats have challenged the sufficiency of non-interference with rights in combating domination, and argued for the importance of political participation and access to public deliberation that goes beyond aggregation of prepolitical preferences. ${ }^{114}$ Some liberals, however, view these theories as supplementing rather than replacing liberalism; the issue hangs on the question of the relationship between theories of justice and theories of democracy, which has not yet been sufficiently addressed. ${ }^{115}$ On the issue of economic domination, Rawls, for example, insists on guaranteeing basic resources for everyone precisely so that "no one need be servilely dependent on others and made to choose between monotonous and routine occupations which are deadening to human thought and sensibility."116 In practice, liberals adopt what Fraser terms 'affirmative' policies like unemployment insurance and income transfers to address inequality instead of 'transformative' policies addressing the economic structures that create massive inequalities in the first place. ${ }^{117}$ Whether this is sufficient or not is open to much dispute.

As to other aspects of objective recognition, while personal relationships have remained off the radar for liberals, the importance of cultural practices within which to express one's identity has been a major impetus for recent developments in liberalism. For example, Yael Tamir's liberal nationalism is based on 'contextual individualism', according to which an autonomous person is capable of making choices, including constitutive choices of national and cultural identity, only "because he is situated in a particular social and cultural environment that offers him evaluative criteria". ${ }^{118}$ She argues that civil

${ }^{114}$ For republicanism, see Philip Pettit, A Theory of Freedom, Polity Press, Cambridge, 2001, and Q. Skinner, Liberty Before Liberalism, Cambridge, Cambridge University Press, 1997; for deliberative democracy, J. Habermas, Die Einbeziehung des Anderen. Studien zur politischen Theorie, Frankfurt, Suhrkamp, 1996; J. Bohman, Public Deliberation. Pluralism, Complexity, and Democracy, Cambridge, Mass., MIT Press, 1996; Richardson 2002, among many others.

${ }_{115}$ See W. Kymlicka, Contemporary Political Philosophy, Oxford, Oxford University Press, 2002, pp. 286-287. Richardson, 2002 is happily a liberal, a republican and a deliberative democrat at the same time!

${ }^{116}$ Rawls, 1971, p. 529.

117 Fraser and Honneth, Redistribution or Recognition?, pp. 72-78. She herself prefers the strategy of 'non-reformist reform', policies that are affirmative in nature and so pragmatically feasible, but "set in motion a trajectory of change in which more radical reforms become practicable over time" (Fraser, 2003, p. 79).

118 Yael Tamir, Liberal Nationalism, Princeton University Press, Princeton, 1993, p. 33 . 
rights and liberties are not sufficient for guaranteeing the existence of such an environment, so that individuals must be granted rights to culture and national self-determination and, as long as they exercise them, have special obligations toward their fellow nationals and flourishing of the culture. 'Nation-building' through conscious propagation of a common language, history, symbols, rituals and customs in schools and the media can and often does create an environment within which citizens have access to collective goods and develop a sense of belonging and solidarity that lends legitimacy to redistributive policies, for example. ${ }^{119}$ However, this threatens liberal neutrality and places minorities and rebels at a disadvantaged position. Some liberals, like Will Kymlicka, support special minority rights precisely as a response to such majority nation-building. ${ }^{120}$ Whether such means suffice to guarantee provision of valuable alternatives without compromising state neutrality is yet another open question. The plausibility of the liberal prohibition of value judgements in public action seems to depend on seeing 'the state' and 'the political' as something opposed to "groups and associations below the level of the state - friends and family ... churches, cultural associations, professional groups and trade unions, universities, and the mass media" ${ }^{121}$ to which liberals relegate assessing the value of various cultural options. The insight of deliberative democrats is that the purpose of democratic procedures is precisely to allow for the public opinion formed within such organisations of civil society to be channelled into the political sphere and into law. ${ }^{122}$ This makes it possible to go beyond liberal neutrality by enlarging the options for exercising personal autonomy through the exercise of political autonomy.

I have been able to give the merest taste of the debates around the social conditions of autonomy within normative political philosophy. What are we left with in the end? It seems liberalism is an easy target to shoot at, but a hard one to hit. Its commitment to providing everyone with the basic goods needed for autonomy gives it a great deal of flexibility in response to conceptions that add more conditions to the

119 See, for example, Tamir, Liberal Nationalism, ch. 3-6. Identification with common institutions and mutual solidarity are naturally requirements of the subjective aspect of Hegelian 'being at home'.

${ }^{120}$ Kymlicka, Contemporary Political Philosophy, pp. 362-365.

${ }^{121}$ Kymlicka, Contemporary Political Philosophy, p. 250.

122 See J. Habermas, Faktizität und Geltung. Beiträge zur Diskurstheorie des Rechts und des demokratischen Rechtsstaats, Frankfurt, Suhrkamp, 1992b, ch. VIII. 
list - if something really is necessary for the autonomous pursuit of any kind of good life, the liberal will (or at least should) happily adopt it. The real issue is whether some of these commitments conflict with other core commitments of liberalism, such as those of limiting the means to individual legal rights and state neutrality. Here empirical questions about which sort of policies best promote the existence of autonomy-conducive relationships cannot be avoided, particularly since many of them are in principle out of direct reach of legislative and administrative means. The kind of Hegelian liberalism I have outlined in this essay could help focus such research and justify the resulting policy proposals on the basis of the internally complex social dimension of autonomy. 